\title{
TRPC6-dependent $\mathrm{Ca}^{2+}$ signaling mediates airway inflammation in response to oxidative stress via ERK pathway
}

Qingzi Chen $\mathbb{1}^{1}$, Yubo Zhou', Lifen Zhou', Zhaodi Fu', Chuntao Yang' ', Lei Zhao', Shuni Li', Yan Chen', Yousen Wu', Zhenwei Ling', Yufeng Wang', Jianrong Huang ${ }^{3}$ and Jianhua Li ${ }^{1}$

\begin{abstract}
Ozone $\left(\mathrm{O}_{3}\right)$ plays an extremely important role in airway inflammation by generating reactive oxygen species (ROS) including hydrogen peroxide, then promoting redox actions and causing oxidative stress. Evidences indicate that TRPC6 (canonical transient receptor potential channel 6) is a redox-regulated $\mathrm{Ca}^{2+}$ permeable nonselective cation channel, but its role in the setting of oxidative stress-related airway inflammation remains unknown. Here, we found that both TRPC6 ${ }^{-1-}$ mice and mice pretreated with SAR7334, a potent TRPC6 inhibitor, were protected from $\mathrm{O}_{3}$-induced airway inflammatory responses. In vitro, both knockdown of TRPC6 expression with shRNA and TRPC6 blockage markedly attenuated the release of cytokines IL-6 and IL-8 induced by $\mathrm{O}_{3}$ or $\mathrm{H}_{2} \mathrm{O}_{2}$ in $16 \mathrm{HBE}$ cells (human bronchial epithelial cell line). Treatment with $\mathrm{O}_{3}$ or $\mathrm{H}_{2} \mathrm{O}_{2}$ enhanced TRPC6 protein expression in vivo and vitro. We also observed that TRPC6-dependent increase of intracellular $\mathrm{Ca}^{2+}$ concentration $\left(\left[\mathrm{Ca}^{2+}\right]_{i}\right)$ was triggered by $\mathrm{H}_{2} \mathrm{O}_{2}$, which consisted of the release from intracellular calcium store and the influx of extracellular $\mathrm{Ca}^{2+}$ and could be further strengthened by 6-h $\mathrm{O}_{3}$ exposure in both $16 \mathrm{HBE}$ cells and HBEpiCs (primary human bronchial epithelial cells). Moreover, we confirmed that the activation of MAPK signals (ERK1/2, p38, JNK) was required for the inflammatory response induced by $\mathrm{O}_{3}$ or $\mathrm{H}_{2} \mathrm{O}_{2}$ while only the phosphorylation of ERK pathway was diminished in the TRPC6knockdown situation. These results demonstrate that oxidative stress regulates TRPC6-mediated $\mathrm{Ca}^{2+}$ cascade, which leads to the activation of ERK pathway and inflammation and could become a potential target to treat oxidative stressassociated airway inflammatory diseases.
\end{abstract}

\section{Introduction}

Abnormal airway inflammation resulting from exposure to various oxidizing ambient pollutants is one of the most common and significant pathogenesis for numerous respiratory diseases, including asthma, chronic obstructive

\footnotetext{
Correspondence: Jianrong Huang (guke16@163.com) or

Jianhua Li (lijianh@gzhmu.edu.cn)

${ }^{1}$ Affiliated Cancer Hospital \& Institute; Key Laboratory of Protein Modification and Degradation, School of Basic Medical Sciences, Guangzhou Medical University, Guangzhou, China

${ }^{2}$ Institute of Pediatrics, Guangzhou Women and Children's Medical Center of Guangzhou Medical University, Guangzhou, China

Full list of author information is available at the end of the article

These authors contributed equally: Qingzi Chen, Yubo Zhou, Lifen Zhou

These authors jointly supervised this work: Jianrong Huang, Jianhua Li

Edited by J.-E. Ricci
}

pulmonary disease (COPD), and lung cancer. Ambient pollutants, such as inhalable dusts, particulate matter (PM), tobacco smoke and ozone $\left(\mathrm{O}_{3}\right)$, have strong ability to generate reactive oxygen species (ROS), accelerate redox actions and trigger oxidative stress. As the first line of defense and major target of inhaled harmful environmental pollutants, bronchial epithelium produces a series of proinflammatory molecules and recruits inflammatory cells into interstitium and airways after suffering oxidative stress, which could further aggravate airway inflammation. However, the molecular mechanisms by which oxidative air pollutants trigger pulmonary inflammation are still elusive. $\mathrm{Ca}^{2+}$, an essential secondary messenger relevant to a variety of cellular processes, plays a key role in mediating

\section{(c) The Author(s) 2020}

(c) (i) Open Access This article is licensed under a Creative Commons Attribution 4.0 International License, which permits use, sharing, adaptation, distribution and reproduction cc) in any medium or format, as long as you give appropriate credit to the original author(s) and the source, provide a link to the Creative Commons license, and indicate if changes were made. The images or other third party material in this article are included in the article's Creative Commons license, unless indicated otherwise in a credit line to the material. If material is not included in the article's Creative Commons license and your intended use is not permitted by statutory regulation or exceeds the permitted use, you will need to obtain permission directly from the copyright holder. To view a copy of this license, visit http://creativecommons.org/licenses/by/4.0/. 
airway inflammatory responses. Rises in $\left[\mathrm{Ca}^{2+}\right]_{\mathrm{i}}$ in pulmonary cells are essential for the activation of inflammatory signal transduction proteins and transcriptions factors ${ }^{1-3}$. Dysregulation of $\left[\mathrm{Ca}^{2+}\right]_{\mathrm{i}}$ homeostasis in bronchial epithelia contributes to pulmonary disease ${ }^{4-6}$. In addition, ROS has been found to be responsible for the activity of various calcium channels ${ }^{7}$. TRPM2, a plasma membrane $\mathrm{Ca}^{2+}$-permeable channel, mediates ROSinduced chemokine production in monocytes ${ }^{8}$. Compared with WT mice, TRPM $2^{-1-}$ mice exhibits enhanced gastric inflammation after infecting with Helicobacter pylori, which is owing to intracellular calcium overloading and augmented oxidative stress ${ }^{9}$. These findings suggest that the abnormality of $\left[\mathrm{Ca}^{2+}\right]_{\mathrm{i}}$ suffered from ROS in pulmonary cells may be involved in airway inflammation.

TRPC6, a $\mathrm{Ca}^{2+}$-permeable non-selective cation channel of the canonical transient receptor potential (TRPC) family, is widely expressed in a number of tissues including brain, heart, lung, ovary, kidney, and vascular tissues ${ }^{10}$. Consistent with its broad expression in lungs, including bronchial epithelial cells, alveolar macrophages and pulmonary vasculature ${ }^{11-13}$, TRPC6 contributes to pulmonary disorders, such as cystic fibrosis, asthma, pulmonary hypertension, COPD, lung edema, and lung fibrosis ${ }^{11,14,15}$. Via analyzing the TRPC6 gene promoter of pulmonary artery smooth muscle cells from patients with idiopathic pulmonary arterial hypertension (IPAH), three single-nucleotide polymorphisms are identified and one of them are found to increase basal gene promoter activity, which may link abnormal transcription of TRPC6 to the activation of NF- $\mathrm{KB}$ and lead to upregulated risk of IPAH $^{16}$. The expression of TRPC6 mRNA in alveolar macrophages isolated from COPD patients is significantly more than healthy controls ${ }^{12}$. Particularly, as a modulator of membrane calcium currents, TRPC6 is newly considered as an essential element in the regulation of inflammatory response ${ }^{17}$. TRPC6 channels have been reported to regulate CXCR2-related chemotaxis via mediating calcium supply ${ }^{18}$. After the activation of TLR4 and generation of DAG, TRPC6-dependent $\mathrm{Ca}^{2+}$ influx into endothelial cells is triggered and cooperated in endotoxin-induced lung inflammation ${ }^{19}$. Moreover, growing evidence points out that TRPC6 acts as a redoxrelated channel, while the definite relation between TRPC6 and ROS seems to be affected by cell specific difference ${ }^{20-23}$. Recently, we reported that TRPC6 is a key element in the regulation of adhesion of neutrophils to bronchial epithelial cell with $\mathrm{O}_{3}$ exposure ${ }^{24}$, while the role and regulatory mechanisms of TRPC6 channel in oxidative stress-induced airway inflammation are still unclear.

Here, we investigated the relevance of TRPC6 in $\mathrm{O}_{3}$ induced airway inflammation in mice and inflammatory response in bronchial epithelial cells. We further explored the involved underlying mechanisms to extrapolate the potential of TRPC6 as target to treat oxidative stressassociated airway inflammation.

\section{Results \\ TRPC6 is required for $\mathrm{O}_{3}$-induced airway inflammatory responses in mice}

We sought to investigate the function of TRPC6 in $\mathrm{O}_{3}$-induced airway inflammatory response by employing TRPC6 $^{-1-}$ mice and SAR7334, a TRPC6-selective inhibitor. As shown in Figs. 1, 2, both TRPC6 $^{-1-}$ mice and mice pretreated with SAR7334 failed to respond to $\mathrm{O}_{3}$ exposure entirely as exhibiting mild airway inflammatory response. TRPC6-deficiency as well as SAR7334 significantly inhibited $\mathrm{O}_{3}$-induced inflammatory cell recruitment in BAL fluid, as reflected by the reduced numbers of neutrophils, macrophages and lymphocytes but not eosinophils, compared with that in $\mathrm{WT}+\mathrm{O}_{3}$ group or $\mathrm{PBS}+\mathrm{O}_{3}$ group (Figs. 1a, 2a). Not only TRPC6 $^{-1-}$ mice but also mice pretreated with SAR7334 had lower total protein, IL-6, IL-8, and TNF- $\alpha$ content in BAL fluid than WT mice had after $\mathrm{O}_{3}$ exposure (Figs. 1b, c, 2b, c). The $\mathrm{O}_{3}$-induced increased lung inflammation scores and inflammatory changes of lung sections were also significantly inhibited by TRPC6deficiency or SAR7334 (Figs. 1d, e, 2d, e). Given the above, TRPC6 contributes to the development of $\mathrm{O}_{3}$-induced airway inflammation in mice.

\section{$\mathrm{Ca}^{2+}$ signal and TRPC6 is required for oxidative stress- induced inflammatory responses in human bronchial epithelial cells}

Ahead of studying the effect of $\mathrm{Ca}^{2+}$ and TRPC6 in oxidative stress-induced inflammatory response, we applied $\mathrm{O}_{3}(100 \mathrm{ppb})$ exposure on $16 \mathrm{HBE}$ cells and found that it made no difference to cell viability when it lasted for $\leq 12 \mathrm{~h}$ (Fig. S1a). The releases of IL- 6 and IL-8 increased after exposure for $6 \mathrm{~h}$ and further augmented till $24 \mathrm{~h}$ post-exposure, but the release level of TNF- $\alpha$ remained unchanged (Fig. 3a). The levels of $\mathrm{O}_{3}$-induced production of IL-6 and IL- 8 were significantly attenuated by removal of extracellular $\mathrm{Ca}^{2+}$ (Fig. 3b), which indicated that the influx of extracellular $\mathrm{Ca}^{2+}$ was a key step in $\mathrm{O}_{3}$ induced releases of inflammatory cytokines. We surmised that TRPC6-mediated $\mathrm{O}_{3}$-induced influx of extracellular $\mathrm{Ca}^{2+}$ as it is a potent monitor of membrane calcium currents. TRPC6 mRNA and protein expression in 16HBE cells was strikingly reduced after transducing with TRPC6 shRNA (shTRPC6) while that in the non-silenced negative control (NC) shRNA group had no difference with that in the control group (Fig. S2.). In parallel, Larixyl Acetate (LA), a potent and specific blocker of TRPC6 channels $\mathrm{s}^{25}$, was administrated at $1,5,10 \mu \mathrm{M}$ concentrations. Importantly, $\mathrm{O}_{3}$-induced releases of IL- 6 and IL-8 were significantly reduced in shTRPC6-treated or LAtreated cells (Fig. 3c, d), suggesting an involvement of 

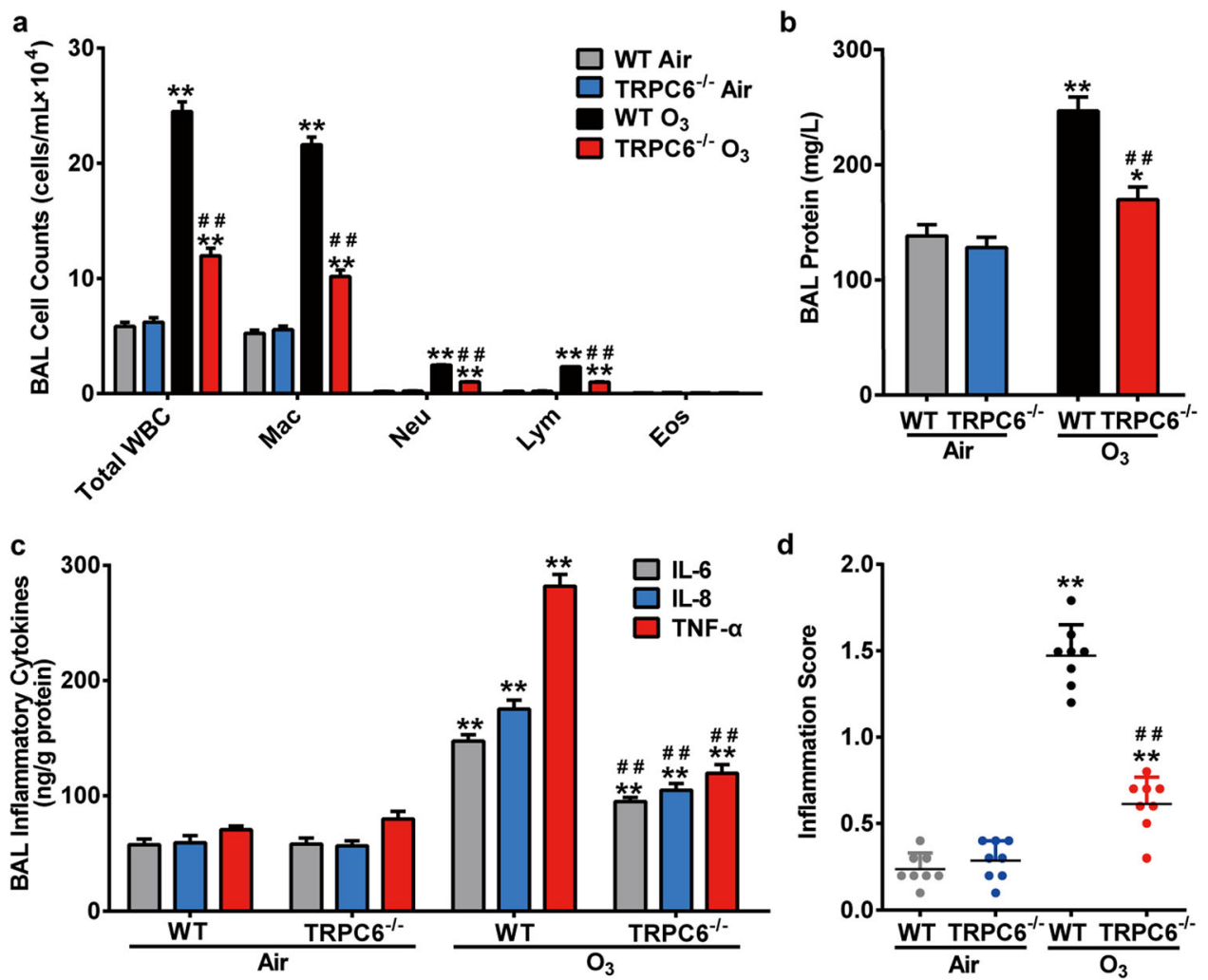

e
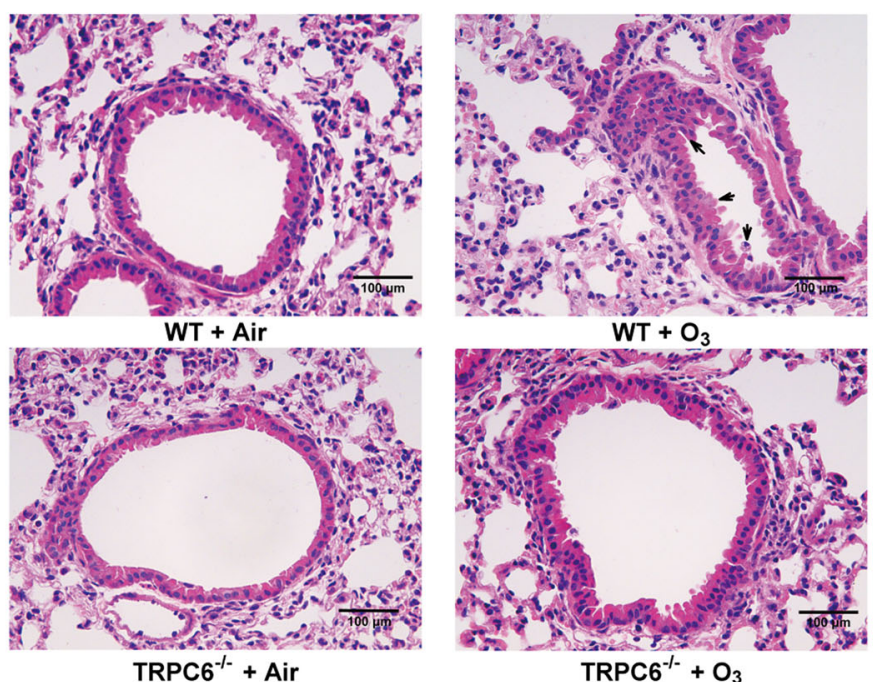

Fig. 1 Effect of TRPC6-deficiency on $\mathrm{O}_{3}$-induced airway inflammation. WT and TRPC $6^{-1-}$ mice were exposed to $\mathrm{O}_{3}(1 \mathrm{ppm})$ for $3 \mathrm{~h}$ every other day (day 1, 3, 5).The mice were anesthetized $24 \mathrm{~h}$ after the last exposure. a-c Total white blood cell counts (Total WBC), macrophage counts (Mac), neutrophil counts (Neu), lymphocyte counts (Lym), eosinophil counts (Eos) (a), total protein content (b) and the release of inflammatory mediators IL6, IL-8, TNF-a (c) in BAL fluid of different groups were compared. $\mathbf{d}$ Inflammation scores in air control and $\mathrm{O}_{3}$-exposed mice. e Representative histological sections of mouse lungs (H\&E staining) after exposure to $\mathrm{O}_{3}$ or air. Black arrows: inflammatory changes. Scale bar: $100 \mu \mathrm{m}$. Results are presented as mean \pm SEM, $n=8$. ${ }^{*} P<0.05$ or ${ }^{* *} P<0.01$ compared with $W T+$ Air group, ${ }^{\# \#} P<0.01$ compared with $W T+\mathrm{O}_{3}$ group.

TRPC6 in $\mathrm{O}_{3}$-induced production of IL-6 and IL-8 in 16HBE cells.

Hydrogen peroxide $\left(\mathrm{H}_{2} \mathrm{O}_{2}\right)$, an oxidant generated during exposure to ambient oxidizing pollutants ${ }^{26}$, is deemed as an intermediate capable of exerting some of its biological effects owing to its diffusibility over membranes and longer half-life than most other $\operatorname{ROS}^{27}$. Thus, $\mathrm{H}_{2} \mathrm{O}_{2}$ was used in current study to further explore the mechanism regarding $\mathrm{O}_{3}$-induced inflammatory response. The viability of $16 \mathrm{HBE}$ cells was not affected 


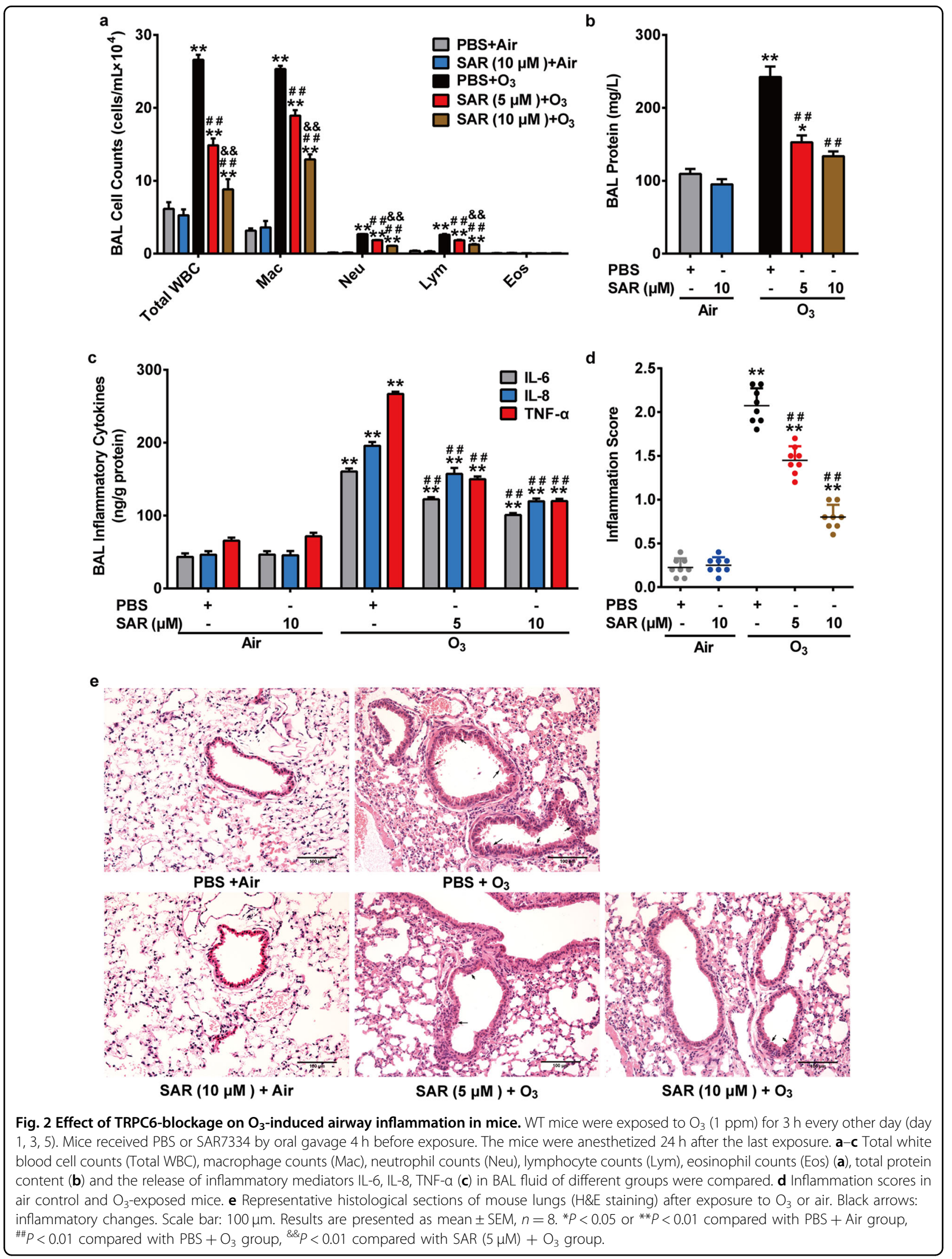




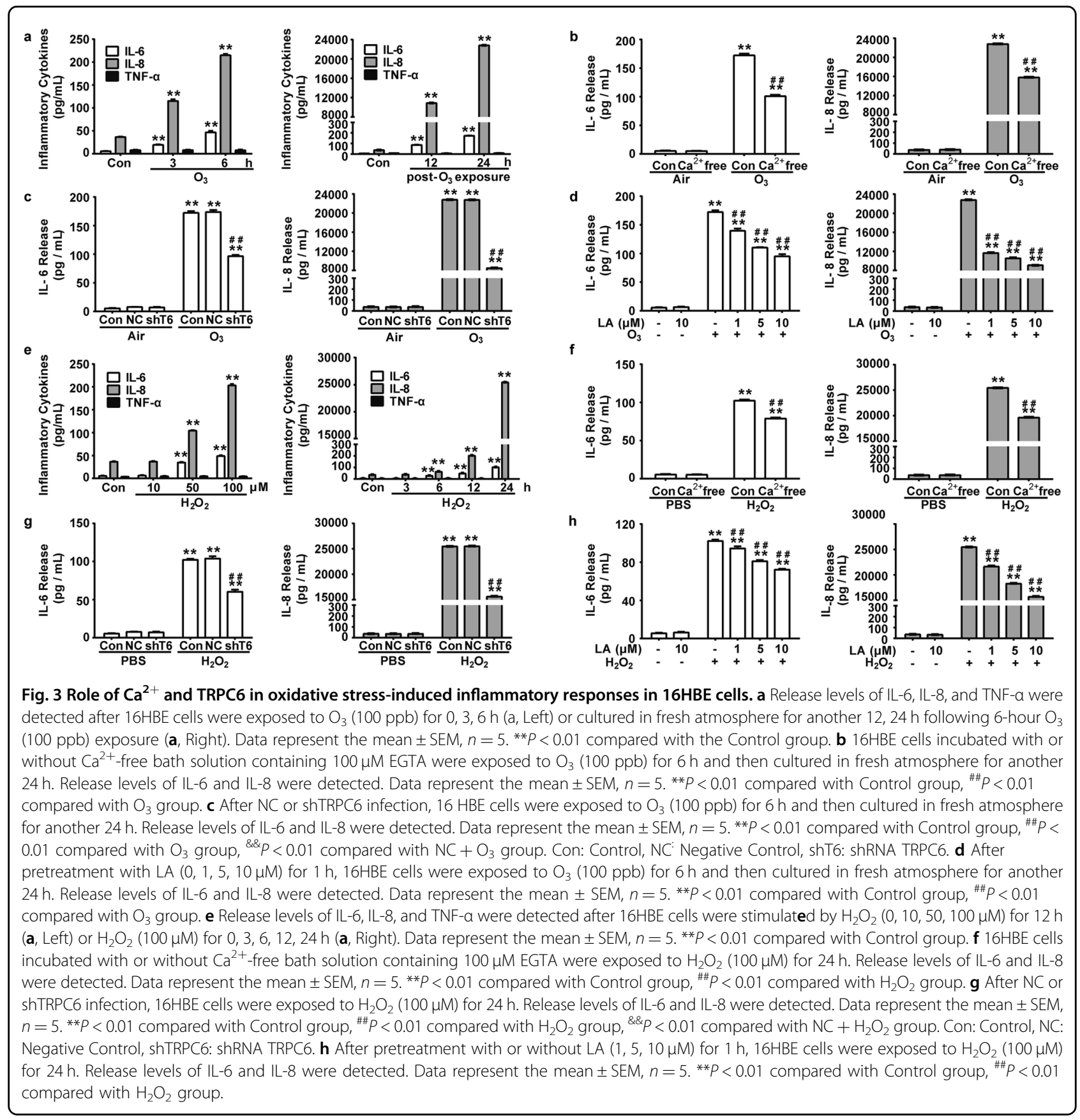

by $\mathrm{H}_{2} \mathrm{O}_{2}$ treatment with $\leq 100 \mu \mathrm{M}$ of dose and $\leq 24 \mathrm{~h}$ of time (Fig. S1b, c). Similar with $\mathrm{O}_{3}$ treatment, $\mathrm{H}_{2} \mathrm{O}_{2}$ increased the releases of inflammatory mediators IL-6 and IL-8 in a concentration-dependent and timedependent manner but not that of TNF- $\alpha$ (Fig. 3e). Consistently, absence of extracellular $\mathrm{Ca}^{2+}$, transfection with shTRPC6 or pretreatment with LA significantly reduced the release levels of IL- 6 and IL- 8 evoked by $\mathrm{H}_{2} \mathrm{O}_{2}$ (Fig. 3f-h), which indicated that $\mathrm{Ca}^{2+}$ signal and TRPC6 contributed to $\mathrm{H}_{2} \mathrm{O}_{2}$-induced production of IL-6 and IL-8 in 16HBE cells. Together, these results suggest that TRPC6 mediates oxidative stress-induced inflammatory responses in human bronchial epithelial cells.

\section{TRPC6 expression is increased by oxidative stress in vivo and vitro}

Since TRPC6-mediated oxidative stress-induced inflammatory responses, we next assessed TRPC6 protein expression in lungs of $\mathrm{O}_{3}$-exposed mice and human bronchial epithelial cells administrated with $\mathrm{O}_{3}$ or $\mathrm{H}_{2} \mathrm{O}_{2}$. Indeed, repeated $\mathrm{O}_{3}$ exposure increased TRPC6 protein expression in lungs (Fig. 4a). Lung section IHC 
a

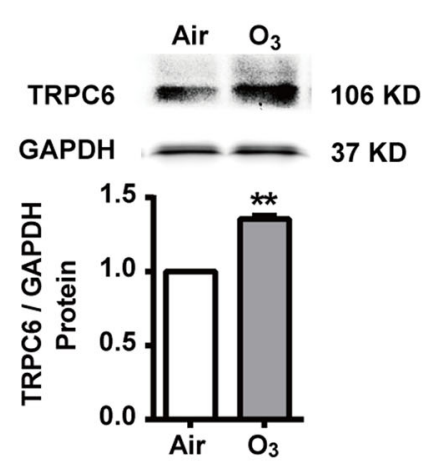

b

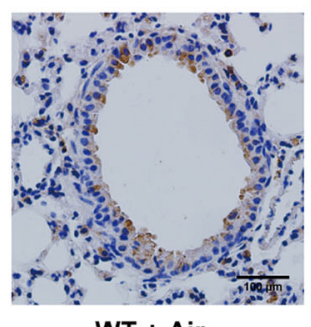

WT + Air

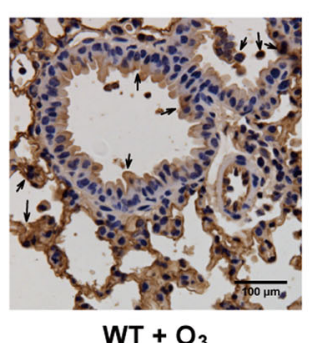

$\mathrm{WT}+\mathrm{O}_{3}$
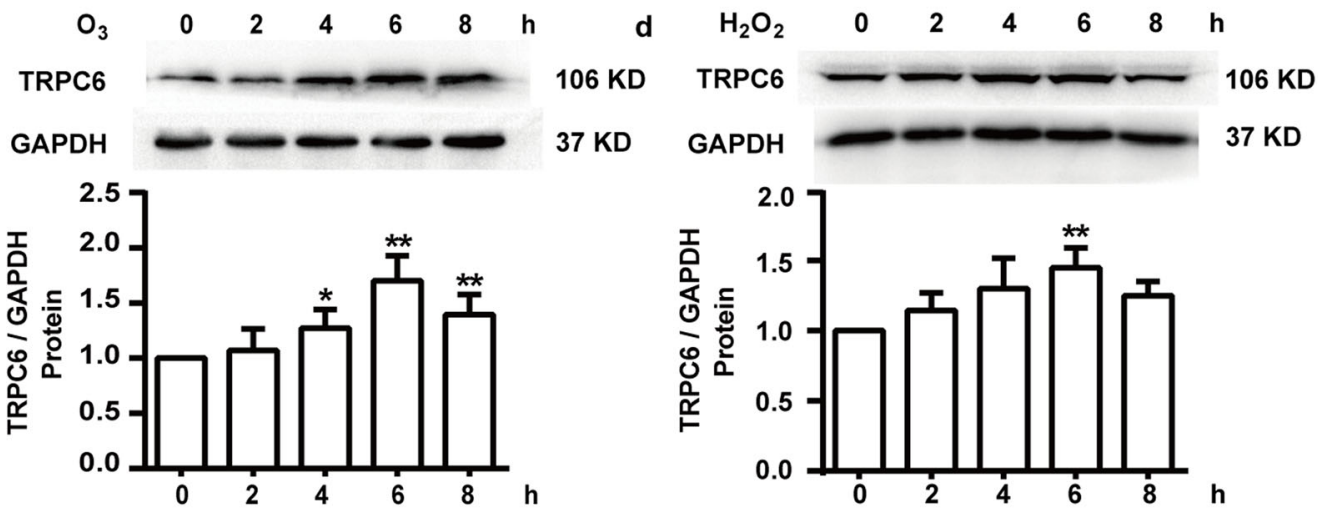

e

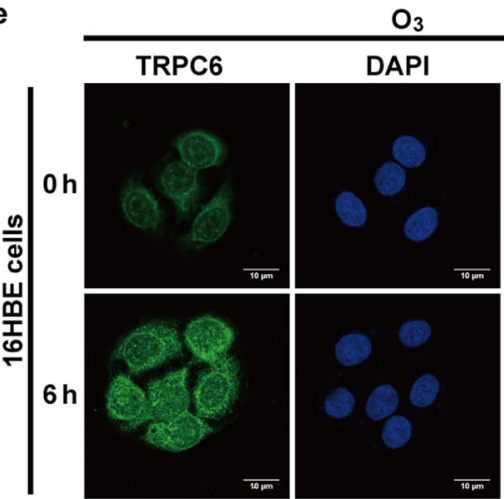

Merge
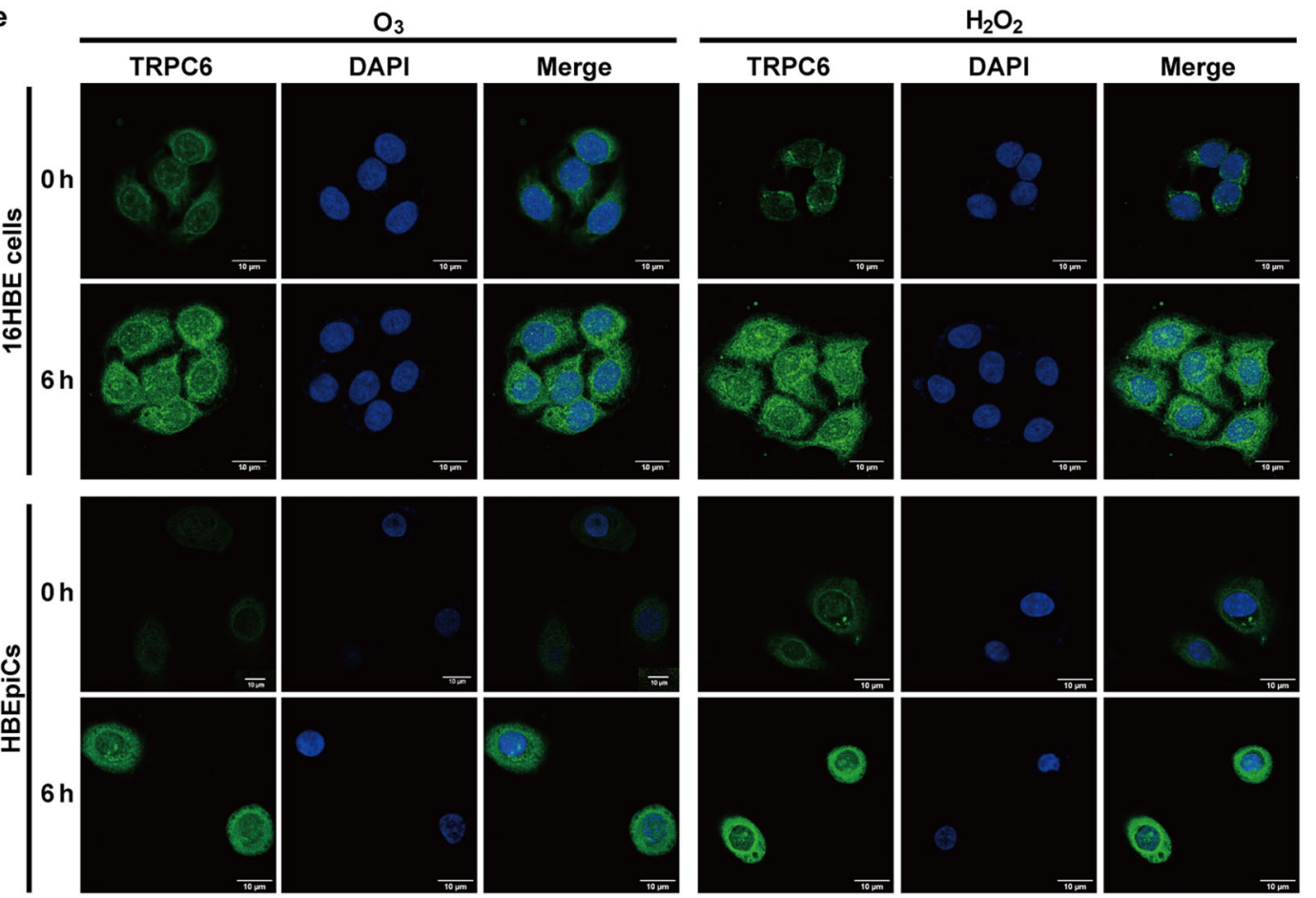

Fig. 4 Effect of oxidative stress on TRPC 6 expression in lung tissue and human bronchial epithelial cells. $\mathbf{a}, \mathbf{b}$ WT mice were exposed to $\mathrm{O}_{3}$ $(1 \mathrm{ppm})$ for $3 \mathrm{~h}$ every other day (day 1,3,5) and were anesthetized $24 \mathrm{~h}$ after the last exposure. TRPC6 expression in lung tissues from mice were analyzed with western blot (a) and immunohistochemistry-stained lung sections (b). Black arrows: epithelial cells and macrophages. Scale bar: $100 \mu \mathrm{m}$. Data represent the mean $\pm \mathrm{SEM}, n=8 .{ }^{* *} P<0.01$ compared with Air group. $\mathbf{c}$, d TRPC6 expression in $16 \mathrm{HBE}$ cells was analyzed by western blot after exposure to $\mathrm{O}_{3}(100 \mathrm{ppb})(\mathbf{c})$ or $\mathrm{H}_{2} \mathrm{O}_{2}(100 \mu \mathrm{M})(\mathbf{d})$ for $0,2,4,6,8$ h. Data represent the mean $\pm \mathrm{SEM}, n=5$. ${ }^{*} P<0.05$ or ${ }^{* *} P<0.01$ compared with $0 \mathrm{~h}$ group. e TRPC 6 expression in 16HBE cells and primary HBEpiCs was analyzed by immunofluorescence after exposure to $\mathrm{O}_{3}(100 \mathrm{ppb})$ or $\mathrm{H}_{2} \mathrm{O}_{2}$ $(100 \mu \mathrm{M})$ for 6 h. Scale bar: $10 \mu \mathrm{m} . n=5$. 


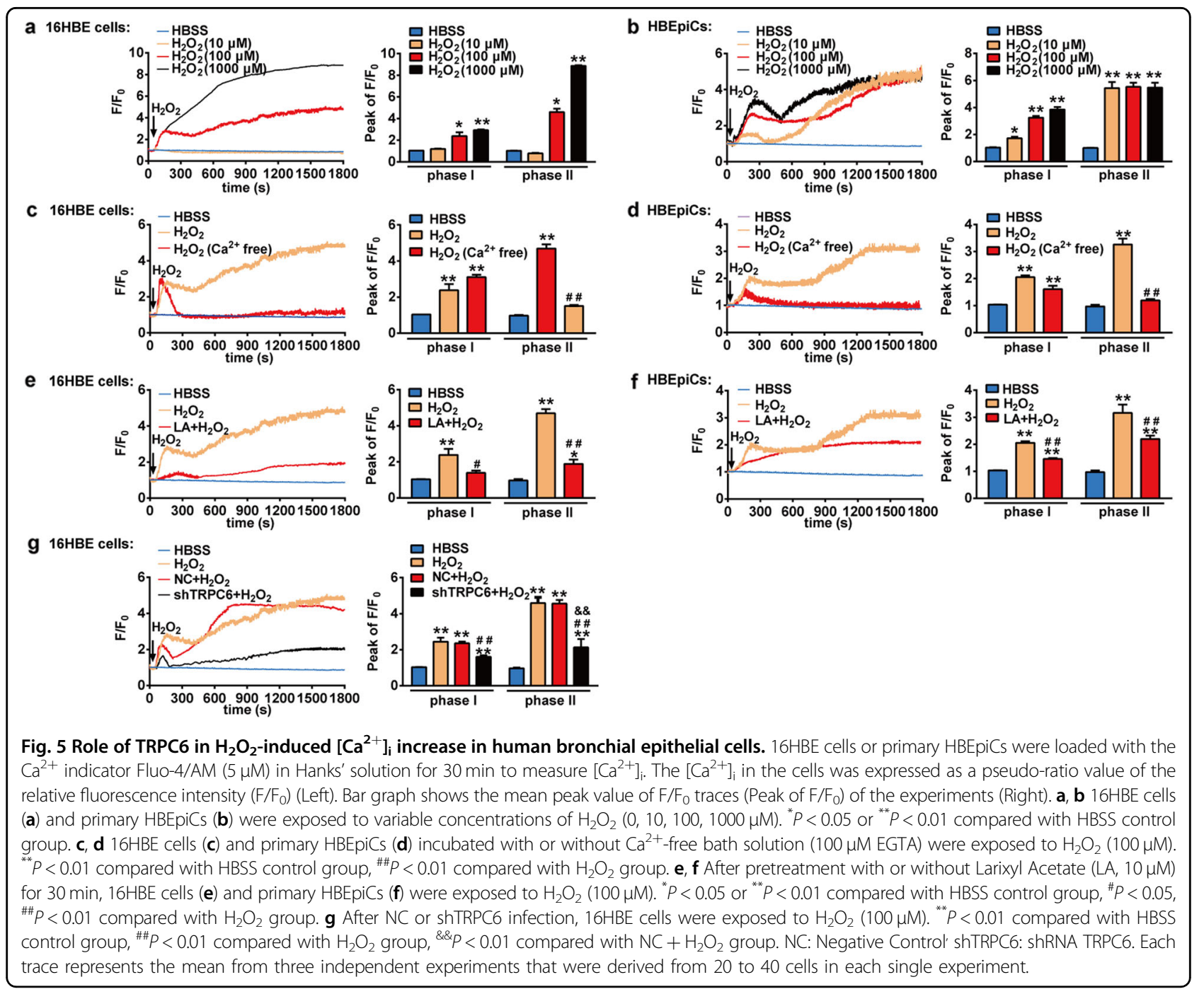

also showed an enhanced TRPC6 protein expression after $\mathrm{O}_{3}$ exposure, mainly localized in bronchial epithelial cells and macrophages (Fig. 4b). As shown in Fig. 4c, d, TRPC6 protein expression was increased and reached a maximum at $6 \mathrm{~h}$ by $\mathrm{O}_{3}(100 \mathrm{ppb})$ exposure or $\mathrm{H}_{2} \mathrm{O}_{2}(100 \mu \mathrm{M})$ stimulation in $16 \mathrm{HBE}$ cells. In view of reports highlighting the differences between primary cells with hTERT or viral genes transduced human cells $^{28,29}$, primary bronchial epithelial cells (HBEpiCs) were employed in parts of our study to further confirm the results obtained from $16 \mathrm{HBE}$ cells. Consistently, in both $16 \mathrm{HBE}$ cells and HBEpiCs, the expression of TRPC6 protein located in both cytomembrane and cytoplasm was upregulated after $\mathrm{O}_{3}(100 \mathrm{ppb})$ or $\mathrm{H}_{2} \mathrm{O}_{2}$ $(100 \mu \mathrm{M})$ exposure for $6 \mathrm{~h}$ (Fig. 4e, f).

\section{TRPC6 mediates $\mathrm{H}_{2} \mathrm{O}_{2}$-induced increase of intracellular calcium in human bronchial epithelial cells}

Previous studies have shown that oxidative stress leads to the disruption of intracellular calcium homeostasis which is capable of activating signal pathway associated with inflammatory response ${ }^{7,30}$. Therefore, we next aimed to study the effect of $\mathrm{H}_{2} \mathrm{O}_{2}$ on the intracellular calcium homeostasis in bronchial epithelial cells and the role of TRPC6 in this progress. Both 16HBE cells and HBEpiCs were stimulated with different concentrations of $\mathrm{H}_{2} \mathrm{O}_{2}$ and calcium-dependent fluorescence was monitored. Calcium imaging results showed that $\mathrm{H}_{2} \mathrm{O}_{2}$-induced intracellular calcium $\left(\left[\mathrm{Ca}^{2+}\right]_{\mathrm{i}}\right)$ increase in a concentration-dependent manner (Fig. 5a, b). Interestingly, treatment with $100 \mu \mathrm{M}$ $\mathrm{H}_{2} \mathrm{O}_{2}$ caused a fast $\left[\mathrm{Ca}^{2+}\right]_{\mathrm{i}}$ increase (phase I) attaining $2.4 \pm$ 0.3 folds within $2 \mathrm{~min}$ in $16 \mathrm{HBE}$ cells. A slight decline to $2.1 \pm 0.1$ folds followed and lasted for about $2 \mathrm{~min}$. Beyond this phase, $\left[\mathrm{Ca}^{2+}\right]_{\mathrm{i}}$ increased slowly and reached a plateau of 4.6 folds 25 min after stimulation (phase II). $1000 \mu \mathrm{M} \mathrm{H}_{2} \mathrm{O}_{2}$ caused a faster and more significant $\left[\mathrm{Ca}^{2+}\right]_{\mathrm{i}}$ increase in cells which reached the plateau of 8.8 folds 25 min after stimulation (Fig. 5a). Intriguingly, compared with 16HBE cells, $\mathrm{HBEpiCs}$ were more sensitive to oxidative stress that $10 \mu \mathrm{M}$ $\mathrm{H}_{2} \mathrm{O}_{2}$ was capable to trigger this increase (Fig. 5b). To 
analyze the source of increased $\left[\mathrm{Ca}^{2+}\right]_{\mathrm{i}}, \mathrm{Ca}^{2+}$-free buffer (containing $5 \mathrm{mM}$ EGTA) was applied. Notably, the initial increase of $\left[\mathrm{Ca}^{2+}\right]_{i}$ (phase I) induced by $\mathrm{H}_{2} \mathrm{O}_{2}$ $(100 \mu \mathrm{M})$ was not influenced while the late $\left[\mathrm{Ca}^{2+}\right]_{\mathrm{i}}$ increase (phase II) was significantly inhibited (Fig. 5c, d), suggesting that $100 \mu \mathrm{M} \mathrm{H}_{2} \mathrm{O}_{2}$-induced increase of $\left[\mathrm{Ca}^{2+}\right]_{\mathrm{i}}$ was composed by intracellular calcium store release (phase I) and extracellular $\mathrm{Ca}^{2+}$ influx (phase II), mainly the latter. Moreover, both the phase I and phase II of the $\mathrm{H}_{2} \mathrm{O}_{2}$ induced $\left[\mathrm{Ca}^{2+}\right]_{i}$ increase were attenuated by pretreatment with the TRPC6 inhibitor LA $(10 \mu \mathrm{M})$ and the inhibition of phase II was more salient (Fig. 5e, f). Similarly, knockdown of TRPC6 markedly inhibited $100 \mu \mathrm{M} \mathrm{H} \mathrm{H}_{2} \mathrm{O}_{2}$-induced $\left[\mathrm{Ca}^{2}\right.$ $\left.{ }^{+}\right]_{\mathrm{i}}$ increase in $16 \mathrm{HBE}$ cells (Fig. $5 \mathrm{~g}$ ). Owing to the relatively short lifespan of primary HBEpiCs, which limits total number of times of subculturing, the experiment in the effect of shTRPC6 on $\mathrm{H}_{2} \mathrm{O}_{2}$-induced $\left[\mathrm{Ca}^{2+}\right]_{\mathrm{i}}$ increase was unable to carry on. Taken together, these results show that TRPC6 mediates $\mathrm{H}_{2} \mathrm{O}_{2}$-evoked increase in $\left[\mathrm{Ca}^{2+}\right]_{i}$ via the release of intracellular calcium store and the influx of extracellular $\mathrm{Ca}^{2+}$.

\section{$\mathrm{O}_{3}$ amplifies $\mathrm{H}_{2} \mathrm{O}_{2}$-triggered increase of $\left[\mathrm{Ca}^{2+}\right]_{\mathrm{i}}$ via TRPC6 in human bronchial epithelial cells}

We then speculated that $\mathrm{O}_{3}$ exposure made the cells more sensitive to oxidative stress which resulted in more serious inflammatory responses and oxidative injury. As shown in Fig. 6a, b, $\mathrm{O}_{3}(100 \mathrm{ppb})$ exposure for $6 \mathrm{~h}$ further amplified $\mathrm{H}_{2} \mathrm{O}_{2}$-triggered $\left[\mathrm{Ca}^{2+}\right]_{\mathrm{i}}$ increase in $16 \mathrm{HBE}$ cells and primary HBEpiCs, displayed as augment of the phase II but no change in the phase I, and both phase I and phase II were significantly abolished by

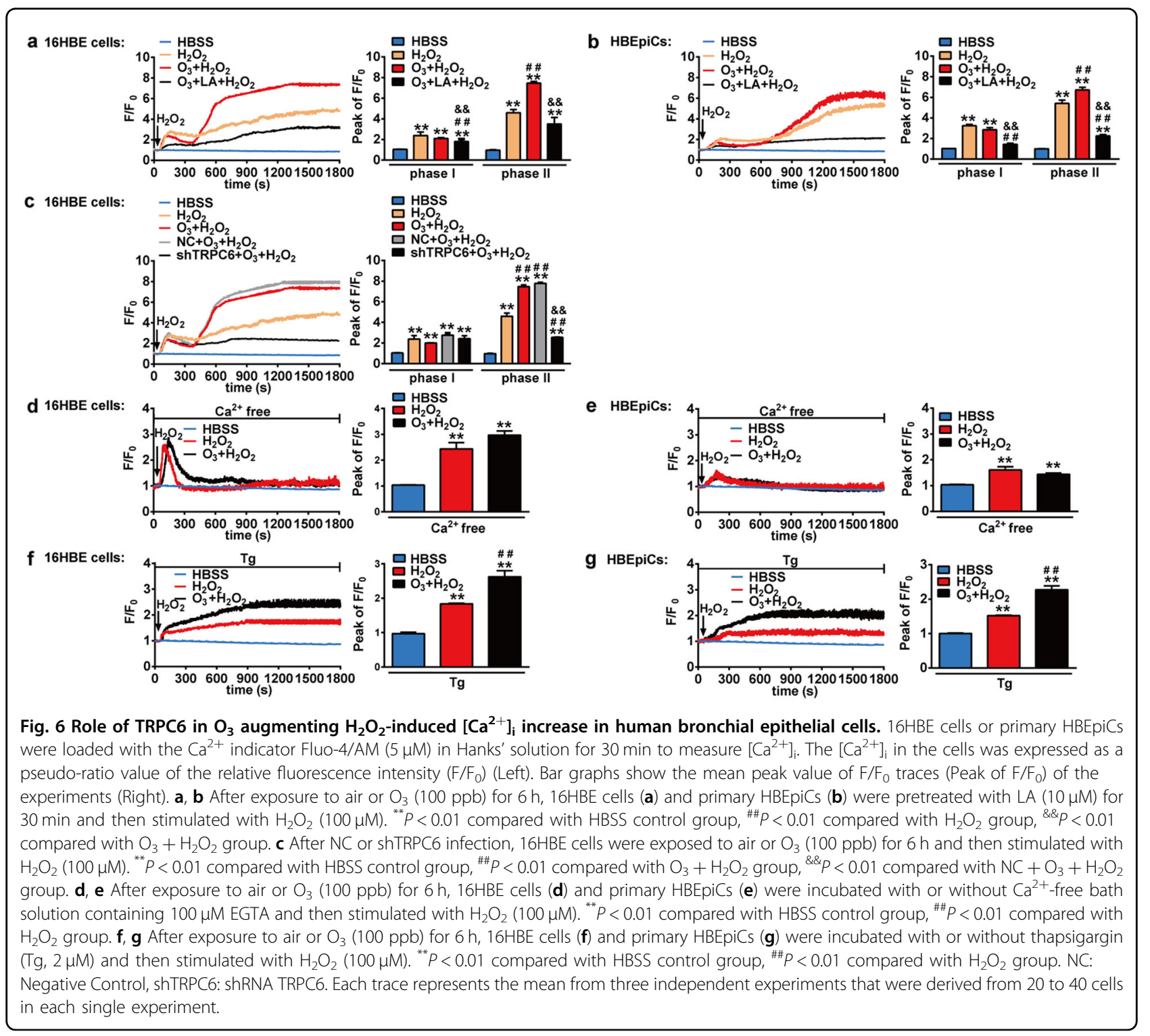


pretreatment with LA $(10 \mu \mathrm{M})$ for $1 \mathrm{~h}$. The phase II of $\mathrm{H}_{2} \mathrm{O}_{2}$-induced $\left[\mathrm{Ca}^{2+}\right]_{\mathrm{i}}$ increase after $\mathrm{O}_{3}(100 \mathrm{ppb})$ exposure was inhibited by shTRPC6 in 16HBE cells (Fig. 6c). These results suggest that TRPC6 has a major role in $\mathrm{O}_{3}$-induced augmenting sensitivity to oxidative stress in bronchial epithelial cells.

Then we sought to further address the source of 6-h $\mathrm{O}_{3}$ exposure-induced augment of $\left[\mathrm{Ca}^{2+}\right]_{\mathrm{i}}$ increase. By incubating cells with $\mathrm{Ca}^{2+}$-free bath solution containing $100 \mu \mathrm{M}$ EGTA, we found that $\mathrm{O}_{3}$ exposure made no difference to $\mathrm{H}_{2} \mathrm{O}_{2}$-induced release of intracellular calcium storage (Fig. 6d, e) but enhanced the influx of extracellular $\mathrm{Ca}^{2+}$ when the intracellular calcium storage was depleted by pretreatment with thapsigargin ( $\mathrm{Tg}$, $2 \mu \mathrm{M}$ ) (Fig. 6f, g). Therefore, $\mathrm{O}_{3}$-amplified sensibility to oxidative stress via TRPC6 is mainly dependent on enhancing the influx of extracellular $\mathrm{Ca}^{2+}$ in the bronchial epithelial cells.

\section{MAPK signal pathway contributes to oxidative stress-} induced inflammatory response in bronchial epithelial cells

It has been established that MAPK (ERK, p38, JNK) was involved in oxidative stress-induced inflammatory response in lungs ${ }^{31}$. Thus we investigated whether the inflammatory response in this research was mediated by MAPK signal pathway. Results unveiled that after exposure to $\mathrm{O}_{3}(100 \mathrm{ppb})$ or $\mathrm{H}_{2} \mathrm{O}_{2}(100 \mu \mathrm{M})$ for 15 or $30 \mathrm{~min}$, the phosphorylation levels of ERK1/2, p38 and JNK signaling pathways were significantly increased in 16HBE cells (Fig. 7a-c). Pretreatment with PD98059 (ERK inhibitor), SB203580 (p38 inhibitor) or SP600125 (JNK inhibitor) inhibited $\mathrm{O}_{3}$ or $\mathrm{H}_{2} \mathrm{O}_{2}$-augmented release of inflammatory factors IL-6 and IL-8 in 16HBE cells in a dose-dependent manner (Fig. $7 \mathrm{~d}-\mathrm{f}$ ), suggesting these MAPK signals participated in $\mathrm{O}_{3}$ or $\mathrm{H}_{2} \mathrm{O}_{2}$-induced inflammatory response. These data demonstrate that MAPK signal pathway is responsible for oxidative stress-induced inflammatory response in bronchial epithelial cells.

\section{TRPC6 is required for the oxidative stress-induced activation of ERK pathway}

We next investigated the role of TRPC6 in oxidative stress-induced activation of MAPK pathways. Deficiency of TRPC6 by shTRPC6 significantly reversed $\mathrm{O}_{3}$ or $\mathrm{H}_{2} \mathrm{O}_{2}$-induced increase of phosphorylation levels of ERK but made no difference to those of p38 and JNK (Fig. 8a, b), indicating that TRPC6-mediated oxidative stressinduced activation of ERK pathway rather than $\mathrm{p} 38$ or JNK in bronchial epithelial cells. Additionally, pretreatment with MAPK inhibitors (PD98059, SB203580, or SP600125) did not affect the $\mathrm{H}_{2} \mathrm{O}_{2}$-induced $\left[\mathrm{Ca}^{2+}\right]_{\mathrm{i}}$ increase (Fig. 8c), which suggested that TRPC6-mediated $\left[\mathrm{Ca}^{2+}\right]_{\mathrm{i}}$ increase was not dependent on the MAPK pathways. Taken together, these experiments suggest that
ERK acts as the downstream of TRPC6 in oxidative stress-induced inflammatory response.

\section{Discussion}

The major findings of our study demonstrated for the first time that TRPC6 acted as an oxidative stress sensor in bronchial epithelium and mediated oxidants-induced inflammatory responses via activating ERK. Exposure to oxidizing air pollutants (e.g. $\mathrm{O}_{3}$ ) and the following increase of ROS in lungs (e.g. $\mathrm{H}_{2} \mathrm{O}_{2}$ ) are key causative factors in the development of chronic inflammatory respiratory diseases. Here we found that $\mathrm{O}_{3}$ exposure to mice motivated severe airway inflammation and potentiated the expression of TRPC6 protein in lungs, especially in bronchial epithelium and alveolar macrophages. Utilizing TRPC6 ${ }^{-1-}$ mice and TRPC6-selective inhibitor, we found that TRPC6 contributed to $\mathrm{O}_{3}$ inhalation-induced airway inflammation. In vitro experiments we confirmed the requirement of TRPC6 for oxidative stress-induced inflammatory responses and the upregulation of the TRPC6 protein expression by $\mathrm{O}_{3}$ or $\mathrm{H}_{2} \mathrm{O}_{2}$ stimulation in human bronchial epithelial cells. Furthermore, $\mathrm{H}_{2} \mathrm{O}_{2}$ triggered $\left[\mathrm{Ca}^{2+}\right]_{\mathrm{i}}$ increase composing of the release of intracellular $\mathrm{Ca}^{2+}$ store and influx of extracellular $\mathrm{Ca}^{2+}$ was mediated by TRPC6 channels. Importantly, $\mathrm{O}_{3}$ exposure enhanced the influx of extracellular $\mathrm{Ca}^{2+}$ triggered by $\mathrm{H}_{2} \mathrm{O}_{2}$, which was abolished by TRPC6 knockdown or blockage. Moreover, MAPK signal pathway (ERK, p38, JNK) was responsible for the inflammatory response and ERK pathway acted as the downstream of TRPC6 in these experiments. Therefore, we concluded that TRPC6 regulated oxidative inflammatory responses induced by $\mathrm{O}_{3}$ or $\mathrm{H}_{2} \mathrm{O}_{2}$ through activating ERK pathway.

It is well known that exposure to $\mathrm{O}_{3}$ induces oxidative injury to the respiratory tract, causes inflammatory responses and triggers clinical symptoms of a series of chronic respiratory disease such as asthma, bronchitis and $\mathrm{COPD}^{32,33}$. However, the underlying mechanisms of $\mathrm{O}_{3}$ induced oxidative injury have not yet been fully defined. TRPC6, a lipid-dependent membrane protein acting as non-selective cation channels conducting $\mathrm{Na}^{+}$and $\mathrm{Ca}^{2+}$, is highly expressed in the lung and most studied in pulmonary diseases among TRPC channels ${ }^{34,35}$. We previously reported that TRPC6 channels contribute to LPSinduced inflammatory response in human bronchial epithelial cells, which implies that TRPC6 may be a therapeutic target in bronchial epithelial inflammation ${ }^{36}$. It has been well described in many cell types and tissues that the activity of TRPC6 channel is redox-sensitive, while it seems to have different phenotype according to different cell types ${ }^{23,37}$. In podocytes, HEK $293 \mathrm{~T}$ cells and vascular myocytes, ROS not only activates TRPC6 already in the plasma membrane but also upregulates the expression of TRPC6 in the surface ${ }^{38-42}$. Some other studies show that 

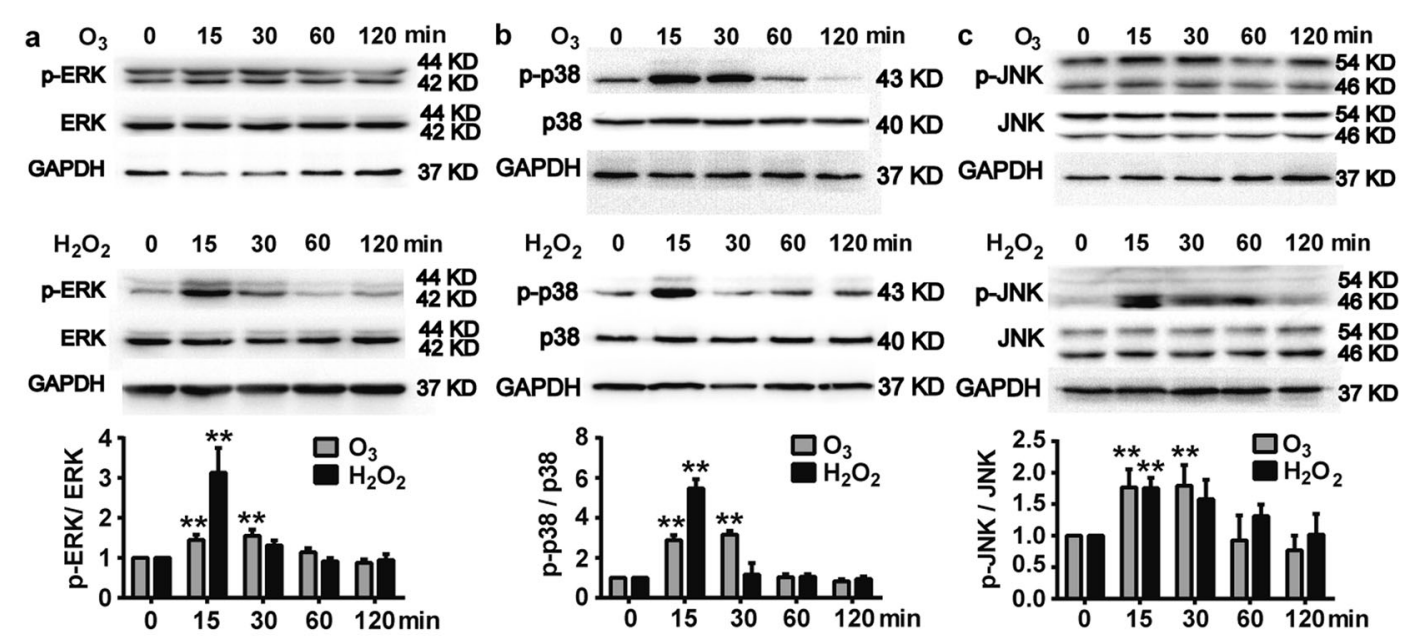

d
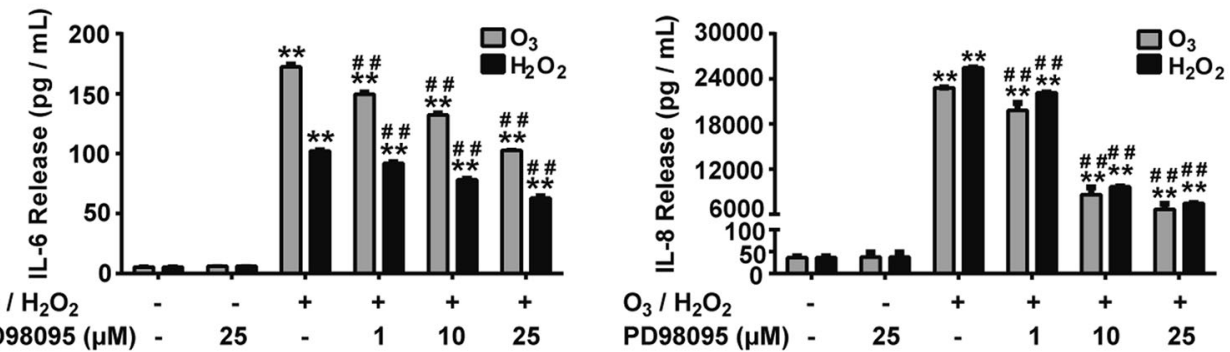

e
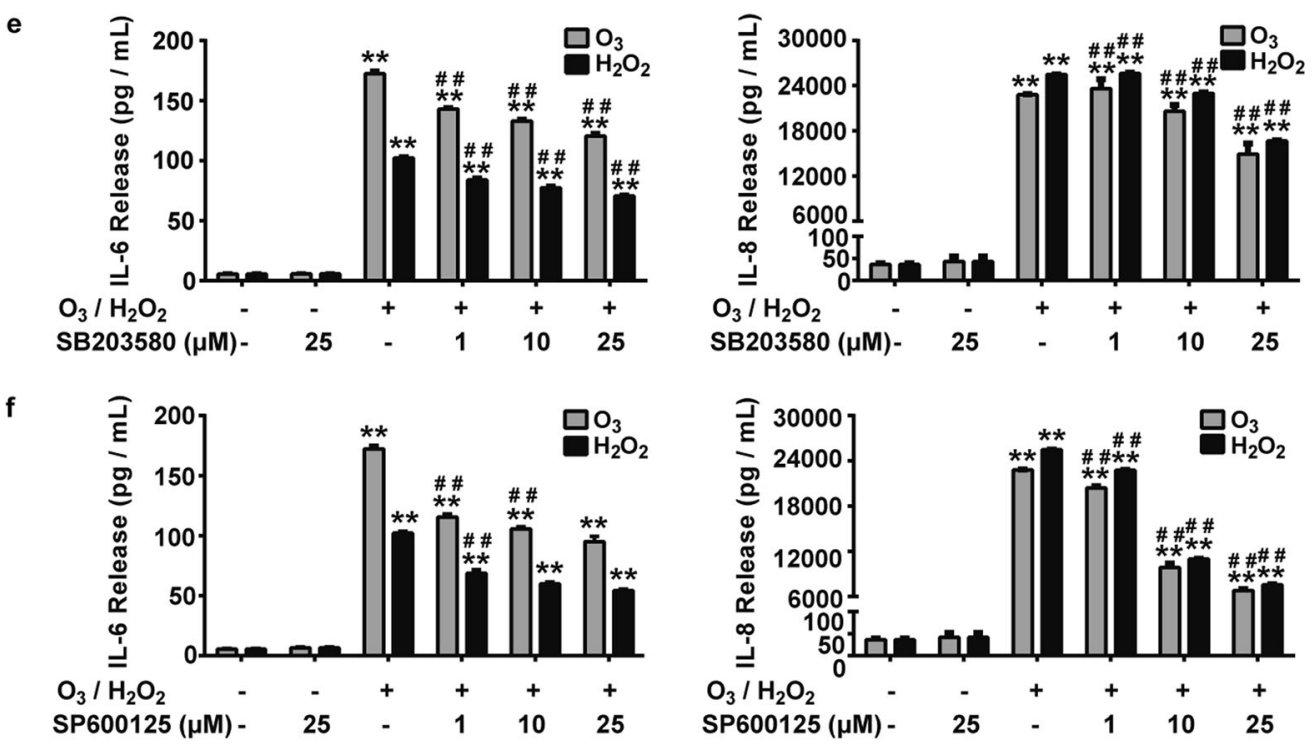

Fig. 7 Role of MAPK signal pathway in oxidative stress-induced inflammatory response in bronchial epithelial cells. a-c Western blot analysis of phosphorylation protein expression of ERK (a), p38 (b) and JNK (c) after $16 \mathrm{HBE}$ cells were stimulated with $\mathrm{O}_{3}(100 \mathrm{ppb})$ or $\mathrm{H}_{2} \mathrm{O}_{2}(100 \mu \mathrm{\mu M})$ for $0,15,30,60,120$ min. ${ }^{* *} P<0.01$ compared with 0-min group. $\mathbf{d}$-f After pretreatment with or without PD98059 $(1,10,25 \mu \mathrm{M})(\mathbf{d})$, SB203580 (1, 10 , $25 \mu \mathrm{M})(\mathbf{e})$ or SP600125 (1, 10, $25 \mu \mathrm{M})(\mathbf{f})$ for $1 \mathrm{~h}, 16 \mathrm{HBE}$ cells were stimulated with $\mathrm{O}_{3}(100 \mathrm{ppb})$ for $6 \mathrm{~h}$ followed by continuing culture for another $24 \mathrm{~h}$ or stimulated with $\mathrm{H}_{2} \mathrm{O}_{2}(100 \mu \mathrm{M})$ for $24 \mathrm{~h}$. Release levels of IL-6 and IL-8 were detected. Data represent the mean $\pm \mathrm{SEM}, n=5$. ${ }^{* *} P<0.01$ compared with Control group, ${ }^{\#} \mathrm{P}<0.01$ compared with $\mathrm{H}_{2} \mathrm{O}_{2}$ or $\mathrm{O}_{3}$ group.

ROS decreases the activity and abundance of TRPC6 protein in mesangial cells ${ }^{20,43}$. However, it has been rarely described whether ROS activate TRPC6 channel, the underlying mechanisms of the following $\mathrm{Ca}^{2+}$ transportation and the further effects in respiratory system. Here, we found that $\mathrm{O}_{3}$ exposure led to the increase of TRPC6 protein expression in mice lungs (Fig. 4a, b). $\mathrm{H}_{2} \mathrm{O}_{2}$, a diffusible and ubiquitous second messenger, 
a

$$
\frac{\text { Air }}{\text { Con NC shT6 Con NC shT6 }}
$$

p-ERK ——- $-44 \mathrm{KD}$

ERK - - - - - $44 \mathrm{~KB}$

GAPDH - - - - $-37 \mathrm{KD}$

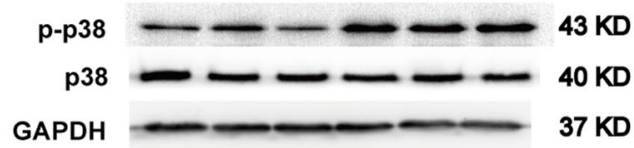

p-JNK ……
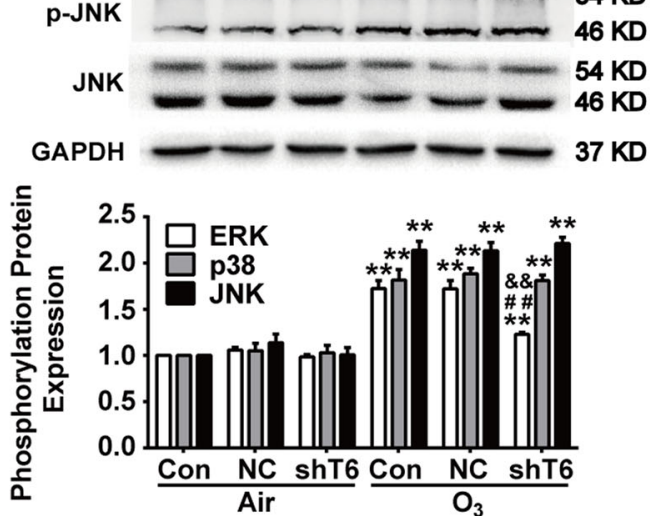

b
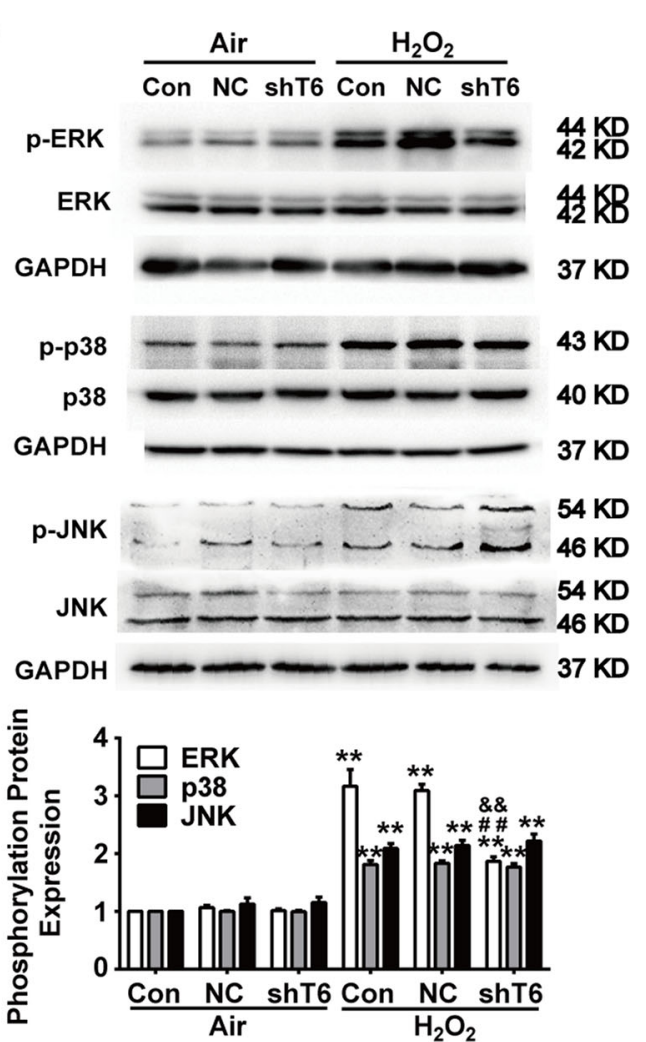

C
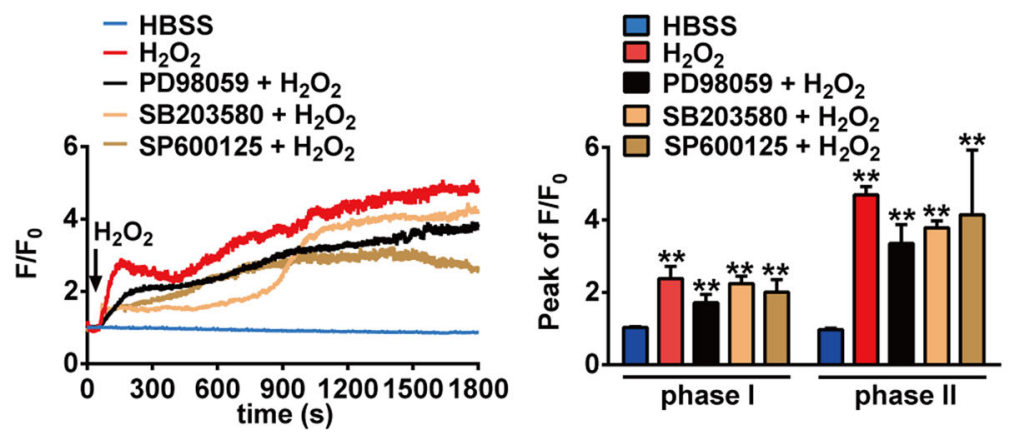

Fig. 8 Role of TRPC6 in oxidative stress-induced activation of MAPK signal pathway. a, b After NC or shTRPC6 infection, 16HBE cells were exposed to $\mathrm{O}_{3}(100 \mathrm{ppb})$ for $30 \mathrm{~min}(\mathbf{a})$ or $\mathrm{H}_{2} \mathrm{O}_{2}(100 \mu \mathrm{M})$ for $15 \mathrm{~min}(\mathbf{b})$ respectively. Phosphorylation levels of ERK, p38, JNK were analyzed by western blot. Data represent the mean $\pm \mathrm{SEM}, n=5 .{ }^{* *} P<0.01$ compared with Control group, ${ }^{\# \#} P<0.01$ compared with $\mathrm{O}_{3}$ or $\mathrm{H}_{2} \mathrm{O}_{2}$ group, \&\& $P<0.01$ compared with $\mathrm{NC}+\mathrm{O}_{3}$ or $\mathrm{NC}+\mathrm{H}_{2} \mathrm{O}_{2}$ group. c $16 \mathrm{HBE}$ cells were loaded with the $\mathrm{Ca}^{2+}$ indicator Fluo-4/AM (5 $\mu \mathrm{M}$ ) in Hanks' solution for 30 min to measure $\left[\mathrm{Ca}^{2+}\right]_{i}$. The $\left[\mathrm{Ca}^{2+}\right]_{i}$ in the cells was expressed as a pseudo-ratio value of the relative fluorescence intensity (F/Fo) (Left). Bar graph shows the mean peak value of $F / F_{0}$ traces (Peak of $\left.F / F_{0}\right)$ of the experiments (Right). After pretreatment with or without PD98059 $(25 \mu \mathrm{M})$, SB203580 (25 $\left.\mu \mathrm{M}\right)$ or SP600125 $(25 \mu \mathrm{M})$ for $1 \mathrm{~h}, 16 \mathrm{HBE}$ cells were stimulated with $\mathrm{H}_{2} \mathrm{O}_{2}(100 \mu \mathrm{M})$. ${ }^{* *} \mathrm{P}<0.01$ compared with HBSS control group. Each trace represents the mean from three independent experiments that were derived from 20 to 40 cells in each single experiment. NC: Negative Control, shT6: ShRNA TRPC6.

contributes to the pathogenesis of several respiratory disease and their exacerbations ${ }^{44}$. Generated in lungs during oxidative pollutants exposure and more stable to readily penetrate the cells, $\mathrm{H}_{2} \mathrm{O}_{2}$ is adopted in many studies to further investigate the mechanism related to ambient oxidants-induced injury. We found that both $\mathrm{O}_{3}$ and $\mathrm{H}_{2} \mathrm{O}_{2}$ enhanced TRPC6 expression in human bronchial epithelial cells (Fig. 4c-e). TRPC6 ${ }^{-1-}$ mice or mice pretreated with TRPC6 inhibitor SAR7334 exposed to $\mathrm{O}_{3}$ revealed attenuated recruitment of neutrophils, macrophages and lymphocytes into airway, release of inflammatory factor IL-6, IL- 8 and TNF- $\alpha$ in BAL fluid and damage of the lungs (Figs. 1, 2). We also confirmed that activation of TRPC6 was required for the release of cytokines after stimulating with $\mathrm{O}_{3}$ or $\mathrm{H}_{2} \mathrm{O}_{2}$ in HBECs (Fig. 3). Although we did not detect the levels of ROS 
in vivo after $\mathrm{O}_{3}$ exposure, it is conceivable that oxidative stress generated by $\mathrm{O}_{3}$ activates TRPC6 channels and upregulates the expression of TRPC6, which leads to the disruptions of intracellular $\mathrm{Ca}^{2+}$ homeostasis and triggers inflammatory response based on the results in vitro (Figs. $3,5,6)$. Surprisingly, the levels of released TNF- $\alpha$ increased after $\mathrm{O}_{3}$ exposure in BAL fluid (Figs. 1c, 2c) but it remained unchanged after stimulating with $\mathrm{O}_{3}$ or $\mathrm{H}_{2} \mathrm{O}_{2}$ in epithelial cells (Fig. 3a, e). We speculated that TNF- $\alpha$ was secreted by other cells but not bronchial epithelial cells.

Although the functional significance of TRPC6mediated $\mathrm{Ca}^{2+}$ transport system in health and disease has gained widespread attention, its activation mechanism is not completely elucidated yet. $\mathrm{H}_{2} \mathrm{O}_{2}$ has been reported to behave pathophysiologically relevantly with a concentration above $100 \mu \mathrm{M}$ while a much lower concentration $(10 \mu \mathrm{M})$ displays a nearly maximal activating effect on TRPC6 channel in HEK293T cells ${ }^{42}$. In the present study, we found that $\mathrm{H}_{2} \mathrm{O}_{2}$ was able to cause concentration-dependently increase of $\left[\mathrm{Ca}^{2+}\right]_{\mathrm{i}}$ in $16 \mathrm{HBE}$ cells and primary HBEpiCs (Fig. 5a, b), which was mainly resulted from the activation of TRPC6 (Fig. 5e-g). Interestingly, $\mathrm{H}_{2} \mathrm{O}_{2}$-induced increase of $\left[\mathrm{Ca}^{2+}\right]_{\mathrm{i}}$ occurred under the concentration of $10 \mu \mathrm{M}$ in primary HBEpiCs while that occurred under $100 \mu \mathrm{M}$ in $16 \mathrm{HBE}$ cells (Fig. 5a, b), suggesting primary HBEpiCs were more sensitive to oxidative stress than16HBE cells were.

Intracellular $\mathrm{Ca}^{2+}$ signal is the most universal and versatile mechanism regulating a wide range of physiological and pathophysiological processes. Store-operated $\mathrm{Ca}^{2+}$ entry and receptor-operated $\mathrm{Ca}^{2+}$ entry are pharmacologically and molecularly distinctive $\mathrm{Ca}^{2+}$ pathways in non-excitable cells. Hence we aimed to illuminate the source of $\mathrm{H}_{2} \mathrm{O}_{2}$-induced increase of $\left[\mathrm{Ca}^{2+}\right]_{\mathrm{i}}$ in human bronchial epithelial cells. In this study we presented that $\mathrm{H}_{2} \mathrm{O}_{2}$ triggered $\left[\mathrm{Ca}^{2+}\right]_{\mathrm{i}}$ increase in two ways: release from intracellular $\mathrm{Ca}^{2+}$ stores and $\mathrm{Ca}^{2+}$ influx into the cells (Fig. 5c, d). To date, although ample evidence suggests that TRPC6 is a DAG-sensitive receptor-operated $\mathrm{Ca}^{2+}$ entry channel ${ }^{45}$, studies about the source of TRPC6-mediated $\mathrm{Ca}^{2+}$ entry generate discordant findings ${ }^{46}$. Indeed, we found that TRPC6-mediated $\left[\mathrm{Ca}^{2+}\right]_{\mathrm{i}}$ increase after $\mathrm{H}_{2} \mathrm{O}_{2}$ exposure consisted of the release of intracellular $\mathrm{Ca}^{2+}$ stores and the influx of extracellular $\mathrm{Ca}^{2+}$ since both phase I and phase II of $\mathrm{H}_{2} \mathrm{O}_{2}$-induced $\left[\mathrm{Ca}^{2+}\right]_{\mathrm{i}}$ increase were inhibited under the situation of TRPC6 blockage or deficiency (Fig. 5e-g). Moreover, the profound augment of $\mathrm{H}_{2} \mathrm{O}_{2}$-induced influx of extracellular $\mathrm{Ca}^{2+}$ by $\mathrm{O}_{3}$ exposure was mainly dependent on TRPC6 channels as the potentiated phase II was abolished by TRPC6 blockage or deficiency (Fig. 6a-c). According to our finding that TRPC6 channels mediated the release of intracellular $\mathrm{Ca}^{2+}$ stores, we speculated that TRPC6 channels participated in store-operated $\mathrm{Ca}^{2+}$ entry although the detailed process still needs further exploration.

MAPK signal pathway is implicated in inflammatory response induced by oxidative stress $^{31}$. Furthermore, previous studies show relationships between the activation of TRPC6 and MAPK signals, which seemed to be context-dependent ${ }^{47,48}$. Here, we found that treatments with $\mathrm{H}_{2} \mathrm{O}_{2}$ or $\mathrm{O}_{3}$ evoked the release of inflammatory factors IL-6 and IL-8 via activating MAPKs (ERK, p38, JNK) (Fig. 7). In addition, deficiency of TRPC6 by shTRPC6 significantly reversed the oxidative stressinduced phosphorylation of ERK but made no effect to that of p38 or JNK (Fig. 8a, b). However, pretreatments with MAPKs inhibitors (PD98059, SB203580, SP600125) did not influence the $\mathrm{H}_{2} \mathrm{O}_{2}$-induced increase of $\left[\mathrm{Ca}^{2+}\right]_{\mathrm{i}}$ in 16HBE cells (Fig. 8c), excluding the possibility that MAPK signal pathway acted as the upstream of TRPC6. Therefore, it is suggested that in human bronchial epithelial cells oxidative stress-aroused inflammatory response was mediated by TRPC6 through regulating $\left[\mathrm{Ca}^{2+}\right]_{\mathrm{i}}$ increase and subsequently activating ERK signal pathway.

In summary, this is the first report demonstrating that TRPC6 is an oxidative stress-sensitive channel which can further mediate inflammatory response via ERK pathway in bronchial epithelial cells. Our result provides a mechanistic understanding of how oxidizing air pollutants lead to airway inflammation. Moreover, we revealed a critical role of intracellular calcium homeostasis in the pathogenesis of such diseases and proposed that targeting TRPC6 might provide a novel therapeutic approach to prevent and treat oxidative stress-induced airway inflammation.

\section{Materials and methods Cell culture}

16HBE cells (Jennio Biotechnology, CHN), a transformed human bronchial epithelial cell line were cultured with 10\% fetal bovine serum (FBS) (10099141; Gibco, USA) as previously outlined ${ }^{36}$. Normal primary human bronchial epithelial cells (HBEpiCs) (3210; ScienCell, USA) were maintained in Bronchial Epithelial Cell Medium (BEpiCM) (3211; ScienCell, USA) with 1\% bronchial epithelial cell growth supplement. Cells were cultured in humidified air with $5 \% \mathrm{CO}_{2}$ at $37^{\circ} \mathrm{C}$. Prior to $\mathrm{O}_{3}$ or $\mathrm{H}_{2} \mathrm{O}_{2}$ (H6520; Sigma-Aldrich, $\mathrm{CHN}$ ) exposure, cells were equilibrated by medium containing $1 \%$ FBS or $0.1 \%$ supplement medium.

\section{Animals}

Eight-week-old female wild-type (WT) and TRPC6deficient $\left(\mathrm{TRPC}^{-1-}{ }^{-}\right.$) mice, on 129SvEv:C57BL/6 J (50:50) crossbred background, were generously provided by Dr. Lutz Birnbaumer (National Institute of Environmental 
Health Sciences, Research Triangle Park, North Carolina) and Dr. Yizheng Wang (Shanghai Institutes of Biological Sciences, State Key Laboratory of Neuroscience, CHN). The TRPC6 knockout genotype was confirmed by RTPCR as previously described ${ }^{24,49}$. Mice were maintained under specific-pathogen-free conditions in the Laboratory Animal Center of Guangzhou Medical University. All animal experiments were carried out under the protocol approved by the Institutional Animal Care and Use Committee of Guangzhou Medical University.

\section{ShRNA experiments to stably silence TRPC6 and quantitative real-time PCR analysis in $16 \mathrm{HBE}$ cells}

$16 \mathrm{HBE}$ cells were transfected with lentivectors expressing TRPC6 shRNA (5'-CCGCUAUGAACUCCU-UG AA-3') or negative control (5'-TTCTCCGAACGTGTCA CGT-3') (Oboi Techonology, CHN). The rate of effective transfection in the cells was monitored by fluorescence microscopy. Over $95 \%$ of cells transfected with lentiviral vectors showed red fluorescence in the experimental and NC groups. The stably transfected cells were picked out with puromycin $(4 \mu \mathrm{g} / \mathrm{mL})$ after being cultured with the lentivirus $(1.66 \times 10 \mathrm{E} 9 \mathrm{TU} / \mathrm{mL})$ at an infection multiplicity of 80 for $24 \mathrm{~h}$. Deficiency of TRPC6 expression was analyzed with real-time RT PCR and western blot.

Total RNAs were obtained from lungs or cultured cells with the TRIzol reagent (15596018; Invitrogen, USA). Real-time PCR was performed with SYBR Premix Taq Kit (DRR081, TaKaRa, CHN) and analyzed with ABI PRISM 7000 Sequence Detection System (Applied Biosystems, USA). All primers were purchased from Invitrogen Corporation (as illustrated in Table 1). The qPCR results were presented as threshold cycle $(\mathrm{Ct})$ value and the relative mRNA quantification was determined using the $2-{ }^{\Delta \Delta \mathrm{ct}}$ method GAPDH as the endogenous control and normalized to a control group.

\section{$\mathrm{O}_{3}$ exposure}

Experiments of $\mathrm{O}_{3}$ exposure in vivo were performed in reference to similar exposure study ${ }^{50}$. Mice were randomly assigned into different groups (eight mice per group) and placed awake in whole-body Plexiglas exposure chamber $(0.55 \mathrm{~m}$ wide, $0.75 \mathrm{~m}$ long, $0.65 \mathrm{~m}$ high) to be exposed to $\mathrm{O}_{3}(1 \mathrm{ppm})$ for $3 \mathrm{~h}$. Another identical exposure chamber was applied for air exposure. Exposure was repeated every other day (day 1,3 , and 5 ) to optimize airway inflammation and did not induce any weight change in the mice (unpublished data). Mice received SAR7334 (HY-15699; MedChem Express, USA), a TRPC6-selective inhibitor, by oral gavage $4 \mathrm{~h}$ before $\mathrm{O}_{3}$ exposure, as reported by Maier and colleagues that pharmacologically effective concentrations of SAR7334 reached optimum 4 hours after oral administration and maintained for several hours ${ }^{51}$. No animals were excluded from the analysis and no blinding was carried out for animal experiments.

Cells were exposed to $\mathrm{O}_{3}(100 \mathrm{ppb})$ with $5 \% \mathrm{CO}_{2}$ humidified air at $37^{\circ} \mathrm{C}$ in the incubator. During exposure, cells were placed on the $3 \mathrm{D}$ rocking platform and tilted gently to an angle of $10^{\circ}$ from the horizontal to each quarter to ensure direct contact with $\mathrm{O}_{3}$. At the end of the exposure, cells were relocated to another incubator with fresh atmosphere. Assays were performed 0-, 12- or 24hour after the exposure. Experiments of $\mathrm{O}_{3}$ exposure in vitro were done referred to similar exposure study ${ }^{52}$. Before $\mathrm{O}_{3}$ exposure, cells were pre-treated with TRPC6selective inhibitor Larixyl Acetate (LA) (02730595; SigmaAldrich, CHN), ERK inhibitor PD98059 (9900; CST, CHN), p38 inhibitor SB203580 (5633; CST, CHN) or JNK inhibitor SP600125 (8177; CST, CHN) for 30 or $60 \mathrm{~min}$.

$\mathrm{O}_{3}$ were generated by HAILEA model HLO-800 ozonizers (HAILEA, CHN) and its concentration within the chamber or incubator was monitored over the exposing period by ambient-air $\mathrm{O}_{3}$ motors (model $106 \mathrm{~L}$; T2B, USA). The mean concentration of $\mathrm{O}_{3}$ within the chambers remained $1 \pm 0.05 \mathrm{ppm}$ or $100 \pm 10 \mathrm{ppb}$ within the incubator during the exposure.

\section{Measurement of inflammation by collection and analysis of BAL fluid or supernatants of cells}

Mice were anesthetized by intraperitoneal injection of pentobarbital sodium $(50 \mathrm{mg} / \mathrm{kg}) 24 \mathrm{~h}$ after the last exposure. To collect bronchoalveolar lavage (BAL) fluid, the left bronchus was clamped, the trachea cannulated and then the right lung lavaged three times slowly with $0.6 \mathrm{~mL}$ ice-cold phosphate-buffered saline (PBS). BAL fluids were centrifuged to isolate cells from samples. The supernatants were collected and stored at $-80^{\circ} \mathrm{C}$ till analysis. To quantify total cell numbers, cell pellets were resuspended with $200 \mu \mathrm{l}$ PBS and multiplied hemacytometer cell counts excluding red blood cells. Differential cell counts stained by Wright-Giema stain set (D10;

Table 1 Sequences of the primers used for quantitative real-time PCR.

\begin{tabular}{llll}
\hline Name & Forward primer (5'-3') & Reverse primer (5'-3') & Product size \\
\hline TRPC6 & GGTGAGCCAGTCTGTTGTCA & TATCTGCTCATGGACTCGGA & 109 bp \\
GAPDH & GAAGGTCGGAGTCAACGG & GGAAGATGGTGATGGGATT & $221 \mathrm{bp}$ \\
\hline
\end{tabular}


Jiancheng Bioengineering Institute, $\mathrm{CHN}$ ) were determined under an optical microscope (EVOS FI; Advanced Microscope Group, USA). At least 200 cells per mouse were counted under $\times 200$ magnification.

The secretion levels of IL-6, IL- 8 and TNF- $\alpha$ in the mentioned supernatants as well as cell medium were detected with commercially available enzyme-linked immunosorbent assay (ELISA) kits (NeoBioscience Technology, $\mathrm{CHN}$ ) according to the instruction manual. Total protein content was determined using a Pierce BCA Protein Assay kit (23225; Thermo Fisher Scientific, USA). The results were expressed as $\mathrm{pg} / \mathrm{mg}$ protein.

\section{Histological analysis}

Following BAL fluid collection, the non-lavaged lungs were cut out and immediately inflated in fresh $4 \%$ paraformaldehyde buffer. Paraffin blocks were prepared from dehydrated tissues and histological sections $(5 \mu \mathrm{m})$ were stained with hematoxylin and eosin (H\&E) for evaluation with a light microscopic (Olympus BX51, JPN).

The severity of lung inflammation in peribronchial and perivascular in H\&E sections was scored on a scale ranging from 0 to 3 where 0 means no inflammation; 1 means mild inflammation with only a few inflammatory cells around bronchial or vascular wall and in alveolar space; 2 means moderate inflammation with patchy inflammatory cells infiltration or localized inflammation around bronchial or vascular wall and in alveolar space and less than one-third of lung cross-sectional area involved; 3 means severe inflammation with diffuse inflammatory cells infiltration and more than one-third of the lung area involved. The scale was made referred to similar study ${ }^{53}$.

\section{Western blot}

After different treatments, 16HBE cells as well as the lung tissue were rinsed with ice-cold PBS. Following steps were performed as previously described ${ }^{36}$. Immunoblotting was detected using Immobilon Western Chemiluminescent HRP Substrate (Millipore, USA) and imaged on ChemiDoc XRS + (Bio-Rad, USA). Western blot bands were quantified by ImageJ 1.41 software and expressed as fold compared to control. Primary specific antibodies used were TRPC6 (CST, \#16716), p44/42 MAPK (ERK1/2) (CST, \#4695) and Phospho-p44/42 MAPK (ERK1/2) (CST, \#4370), p38 MAPK 2103(CST, \#4671), GAPDH (Proteintech, 60004).

\section{Immunohistochemistry (IHC)}

IHC was performed on paraffin-embedded lung tissue sections following standard methods. Lung sections $(5 \mu \mathrm{m})$ were deparaffinized, rehydrated, treated for endogenous peroxidase inhibition and antigen retrieval and then incubated overnight at $4{ }^{\circ} \mathrm{C}$ with primary anti-TRPC6 antibody (dilution 1:100) (ACC-017; Alomone Labs,
Israel), followed by 30-min incubation with Horseradish peroxidase-conjugated secondary antibody (dilution 1:500). Binding was visualized with DAB and counterstained with hematoxylin. Staining images were taken by a confocal laser scanning microscopy (BX51; Olympus, JPN).

\section{Fluorescence measurement of intracellular free calcium $\left(\left[\mathrm{Ca}^{2+}\right]_{\mathrm{i}}\right)$}

16HBE cells and HBEpiCs grown on confocal dishes were washed three times with fresh HBSS and $200 \mu \mathrm{l}$ HBSS was added per dish. The fluorescence intensity of Fluo-4 ( $5 \mu \mathrm{M}$, Molecular Probes Eugene, USA) in the cells was recorded by laser scanning confocal microscopy (Leica TCS SP8, GER). Detailed steps were performed as previously described ${ }^{36} . \mathrm{H}_{2} \mathrm{O}_{2}$ was used to stimulate the cells when the baseline was stable. The $\left[\mathrm{Ca}^{2+}\right]_{\mathrm{i}}$ was expressed as a pseudo-ratio value $\left(\mathrm{F} / \mathrm{F}_{0}\right)$ of the actual fluorescence intensity $(\mathrm{F})$ divided by the average baseline fluorescence intensity $\left(\mathrm{F}_{0}\right)$. The $\mathrm{Ca}^{2+}$-free bath solution contained $100 \mu \mathrm{M}$ EGTA and no $\mathrm{CaCl}_{2}$. Data from 20 to 40 cells were compiled from a single run, and at least three independent experiments were conducted.

\section{Analysis of the expression of TRPC6 protein in the cells by immunofluorescence}

The cells cultured on confocal dishes were fixed with $4 \%$ formaldehyde in $0.1 \mathrm{M}$ PBS for $15 \mathrm{~min}$ and washed three times with $0.1 \mathrm{M}$ PBS. Further details were performed as previously described ${ }^{36} 6$. The cells were incubated with primary specific antibodies against TRPC6 (ACC-017; Alomone Labs, ISR) at $4{ }^{\circ} \mathrm{C}$ overnight and rewarmed for $30 \mathrm{~min}$ subsequently. Following 3 washes with PBS, the cells were incubated with fluorescein isothiocyanate (FITC)-conjugated secondary antibody (Life Technology, USA) for another $1 \mathrm{~h}$. The nuclei were stained by the fluorescent DNA-binding dye 136 4', 6-diamidino-2-phenylindole dihydrochloride (DAPI) (Roche, CHN) for $15 \mathrm{~min}$. Fluorescence pictures were taken under a confocal laser scanning microscopy (SP8; Leica TCS, GER).

\section{Statistical analysis}

Statistical analysis was performed with SPSS 13.0 software. Data expressed as mean \pm SEM represented at least five independent experiments. Statistical significance was determined using Student's test or one-way analysis of variance followed by ANOVA and post hoc Bonferroni or Dunnett T3 test. Differences were considered statistically significant when the probability value $<0.05$ or $<0.01$.

\section{Acknowledgements}

Present address of J.-R. Huang: The Fifth Affiliated Hospital of Guangzhou Medical University. No.621, Gangwan Road, Huangpu District, Guangzhou City, Guangdong Province 510700, China (e-mail: guke16@163.com). In addition, we thank the anonymous reviewers and the editors for their constructive 
suggestions in order to improve our manuscript. We thank Dr. Lutz Birnbaumer (National Institute of Environmental Health Sciences, Research Triangle Park, North Carolina) and Dr. Yizheng Wang (Shanghai Institutes of Biological Sciences, State Key Laboratory of Neuroscience, China) for TRPC6 ${ }^{-1-}$ mice. This work was supported by National Natural Science Foundation of China (81470205), Key Scientific Research Project of Guangzhou Municipal Colleges and Universities (2012C043) and Guangzhou Key Medical Discipline Construction Project Fund.

\section{Author details}

${ }^{1}$ Affiliated Cancer Hospital \& Institute; Key Laboratory of Protein Modification and Degradation, School of Basic Medical Sciences, Guangzhou Medical University, Guangzhou, China. ${ }^{2}$ Institute of Pediatrics, Guangzhou Women and Children's Medical Center of Guangzhou Medical University, Guangzhou, China. ${ }^{3}$ The Fifth Affiliated Hospital of Guangzhou Medical University, Guangzhou, China

\section{Conflict of interest}

The authors declare that they have no conflict of interest.

\section{Publisher's note}

Springer Nature remains neutral with regard to jurisdictional claims in published maps and institutional affiliations.

Supplementary Information accompanies this paper at (https://doi.org/ 10.1038/s41419-020-2360-0).

Received: 17 October 2019 Revised: 13 February 2020 Accepted: 14 February 2020

Published online: 05 March 2020

\section{References}

1. Hsuan, S. L. et al. Pasteurella haemolytica leukotoxin and endotoxin induced cytokine gene expression in bovine alveolar macrophages requires NF-kappaB activation and calcium elevation. Micro. Pathog. 26, 263-273 (1999).

2. Ribeiro, C. M. The role of intracellular calcium signals in inflammatory responses of polarised cystic fibrosis human airway epithelia. Drugs R. D. 7, 17-31 (2006).

3. Ratner, A. J. et al. Cystic fibrosis pathogens activate Ca2+-dependent mitogen-activated protein kinase signaling pathways in airway epithelial cells. J. Biol. Chem. 276, 19267-19275 (2001).

4. Chun, J. \& Prince, A. Ca2+ signaling in airway epithelial cells facilitates leukocyte recruitment and transepithelial migration. J. Leukoc. Biol. 86, 1135-1144 (2009).

5. Davis, C. W. \& Dickey, B. F. Regulated airway goblet cell mucin secretion. Annu. Rev. Physiol. 70, 487-512 (2008).

6. Samanta, K., Bakowski, D. \& Parekh, A. B. Key role for store-operated Ca2+ channels in activating gene expression in human airway bronchial epithelial cells. PLOS ONE 9, e105586 (2014).

7. Gorlach, A., Bertram, K., Hudecova, S. \& Krizanova, O. Calcium and ROS: A mutual interplay. Redox Biol. 6, 260-271 (2015).

8. Yamamoto, S. et al. TRPM2-mediated Ca2+influx induces chemokine production in monocytes that aggravates inflammatory neutrophil infiltration. Nat. Med. 14, 738-747 (2008).

9. Beceiro, S. et al. TRPM2 ion channels regulate macrophage polarization and gastric inflammation during Helicobacter pylori infection. Mucosal Immunol. 10, 493-507 (2017).

10. Abramowitz, J. \& Birnbaumer, L. Physiology and pathophysiology of canonical transient receptor potential channels. FASEB J. 23, 297-328 (2009).

11. Corteling, R. L. et al. Expression of transient receptor potential C 6 and related transient receptor potential family members in human airway smooth muscle and lung tissue. Am. J. Respir. Cell Mol. Biol. 30, 145-154 (2004).

12. Finney-Hayward, T. K. et al. Expression of transient receptor potential C6 channels in human lung macrophages. Am. J. Respir. Cell Mol. Biol. 43, 296-304 (2010).

13. Malczyk, M. et al. The role of transient receptor potential channel 6 channels in the pulmonary vasculature. Front Immunol. 8, 707 (2017).
14. Preti, D., Szallasi, A. \& Patacchini, R. TRP channels as therapeutic targets in airway disorders: a patent review. Expert Opin. Ther. Pat. 22, 663-695 (2012).

15. Dietrich, A. Modulators of transient receptor potential (TRP) channels as therapeutic options in lung disease. Pharmaceuticals 12, 23 (2019).

16. Yu, Y. et al. A functional single-nucleotide polymorphism in the TRPC6 gene promoter associated with idiopathic pulmonary arterial hypertension. Circulation 119, 2313-2322 (2009).

17. Ramirez, G. A. et al. Ion channels and transporters in inflammation: special focus on TRP channels and TRPC6. Cells 7, 70 (2018).

18. Lindemann, $\mathrm{O}$. et al. TRPC6 regulates CXCR2-mediated chemotaxis of murine neutrophils. J. Immunol. 190, 5496-5505 (2013).

19. Tauseef, M. et al. TLR4 activation of TRPC6-dependent calcium signaling mediates endotoxin-induced lung vascular permeability and inflammation. J. Exp. Med. 209, 1953-1968 (2012)

20. Graham, S. et al. Abundance of TRPC6 protein in glomerular mesangial cells is decreased by ROS and PKC in diabetes. Am. J. Physiol. Cell Physiol. 301, C304-C315 (2011).

21. Ding, Y. et al. Reactive oxygen species-mediated TRPC6 protein activation in vascular myocytes, a mechanism for vasoconstrictor-regulated vascular tone. J. Biol. Chem. 286, 31799-31809 (2011).

22. Wang, $Y$. et al. Nuclear factor kappaB mediates suppression of canonical transient receptor potential 6 expression by reactive oxygen species and protein kinase C in kidney cells. J. Biol. Chem. 288, 12852-12865 (2013).

23. Ma, R., Chaudhari, S. \& Li, W. Canonical transient receptor potential 6 channel: a new target of reactive oxygen species in renal physiology and pathology. Antioxid. Redox Signal 25, 732-748 (2016).

24. Chen, Q. Z. et al. TRPC6 modulates adhesion of neutrophils to airway epithelial cells via NF-kappaB activation and ICAM-1 expression with ozone exposure. Exp. Cell Res. 377, 56-66 (2019).

25. Urban, N. et al. Identification and validation of larixyl acetate as a potent TRPC6 inhibitor. Mol. Pharm. 89, 197-213 (2016).

26. Charrier, J. G., McFall, A. S., Richards-Henderson, N. K. \& Anastasio, C. Hydrogen peroxide formation in a surrogate lung fluid by transition metals and quinones present in particulate matter. Environ. Sci. Technol. 48, 7010-7017 (2014).

27. Groeger, G., Quiney, C. \& Cotter, T. G. Hydrogen peroxide as a cell-survival signaling molecule. Antioxid. Redox Signal 11, 2655-2671 (2009).

28. McCullough, S. D. et al. Ozone induces a proinflammatory response in primary human bronchial epithelial cells through mitogen-activated protein kinase activation without nuclear factor-kappaB activation. Am. J. Respir. Cell Mol. Biol. 51, 426-435 (2014).

29. Feng, W. et al. Human normal bronchial epithelial cells: a novel in vitro cell model for toxicity evaluation. PLOS ONE 10, e0123520 (2015).

30. Dolmetsch, R. E., Xu, K. \& Lewis, R. S. Calcium oscillations increase the efficiency and specificity of gene expression. Nature 392, 933-936 (1998).

31. Park, H. S., Kim, S. R. \& Lee, Y. C. Impact of oxidative stress on lung diseases. Respirology 14, 27-38 (2009).

32. Nuvolone, D., Petri, D. \& Voller, F. The effects of ozone on human health. Environ. Sci. Pollut. Res. Int. 25, 8074-8088 (2018).

33. Jerrett, M. et al. Long-term ozone exposure and mortality. N. Engl. J. Med. $\mathbf{3 6 0}$ 1085-1095 (2009).

34. Weissmann, N. et al. Activation of TRPC6 channels is essential for lung ischaemia-reperfusion induced oedema in mice. Nat. Commun. 3, 649 (2012).

35. Preti, D., Szallasi, A. \& Patacchini, R. TRP channels as therapeutic targets in airway disorders: a patent review. Expert Opin. Ther. Pat. 22, 663-695 (2012).

36. Zhou, L. F. et al. TRPC6 contributes to LPS-induced inflammation through ERK1/2 and p38 pathways in bronchial epithelial cells. Am. J. Physiol. Cell Physiol. 314, C278-C288 (2018).

37. Dryer, S. E. \& Kim, E. Y. Permeation and rectification in canonical transient receptor potential-6 (TRPC6) channels. Front. Physiol. 9, 1055 (2018).

38. Ding, $Y$. et al. Reactive oxygen species-mediated TRPC6 protein activation in vascular myocytes, a mechanism for vasoconstrictor-regulated vascular tone. J. Biol. Chem. 286, 31799-31809 (2011).

39. Anderson, M., Roshanravan, H., Khine, J. \& Dryer, S. E. Angiotensin II activation of TRPC 6 channels in rat podocytes requires generation of reactive oxygen species. J. Cell Physiol. 229, 434-442 (2014).

40. Kim, E. Y. et al. NOX2 interacts with podocyte TRPC 6 channels and contributes to their activation by diacylglycerol: essential role of podocin in formation of this complex. Am. J. Physiol. Cell Physiol. 305, C960-C971 (2013).

41. Kim, E. Y., Anderson, M. \& Dryer, S. E. Insulin increases surface expression of TRPC6 channels in podocytes: role of NADPH oxidases and reactive oxygen species. Am. J. Physiol. Ren. Physiol. 302, F298-F307 (2012). 
42. Graham, S. et al. Canonical transient receptor potential 6 (TRPC6), a redoxregulated cation channel. J. Biol. Chem. 285, 23466-23476 (2010).

43. Wang, $Y$. et al. Nuclear factor kappaB mediates suppression of canonical transient receptor potential 6 expression by reactive oxygen species and protein kinase C in kidney cells. J. Biol. Chem. 288, 12852-12865 (2013).

44. Drost, E. M. et al. Oxidative stress and airway inflammation in severe exacerbations of COPD. Thorax 60, 293-300 (2005).

45. Hofmann, T. et al. Direct activation of human TRPC6 and TRPC3 channels by diacylglycerol. Nature 397, 259-263 (1999).

46. Hou, X. et al. Transient receptor potential channel 6 knockdown prevents apoptosis of renal tubular epithelial cells upon oxidative stress via autophagy activation. Cell Death Dis. 9, 1015 (2018).

47. Shirakawa, $\mathrm{H}$. et al. Sphingosine-1-phosphate induces $\mathrm{Ca}(2+)$ signaling and CXCL1 release via TRPC6 channel in astrocytes. Glia 65, 1005-1016 (2017).

48. Shen, B. et al. CAMP activates TRPC6 channels via the phosphatidylinositol 3-kinase (PI3K)-protein kinase B (PKB)-mitogen-activated protein kinase kinase (MEK)-ERK1/2 signaling pathway. J. Biol. Chem. 286 19439-19445 (2011).

49. Dietrich, A. et al. Increased vascular smooth muscle contractility in TRPC6-/mice. Mol. Cell Biol. 25, 6980-6989 (2005).

50. Pichavant, $M$. et al. Ozone exposure in a mouse model induces airway hyperreactivity that requires the presence of natural killer T cells and IL-17. J. Exp. Med. 205, 385-393 (2008).

51. Maier, T. et al. Discovery and pharmacological characterization of a novel potent inhibitor of diacylglycerol-sensitive TRPC cation channels. Br. J. Pharm. 172, 3650-3660 (2015).

52. Wu, W. et al. SRC-mediated EGF receptor activation regulates ozone-induced interleukin 8 expression in human bronchial epithelial cells. Environ. Health Perspect. 123, 231-236 (2015).

53. Michaudel, C. et al. Interleukin-1alpha mediates ozone-induced myeloid differentiation factor-88-dependent epithelial tissue injury and inflammation. Front Immunol. 9, 916 (2018). 